\title{
Lipid Biomarker Record of the Serpentinite-Hosted Ecosystem of the Samail Ophiolite, Oman and Implications for the Search for Biosignatures on Mars
}

\author{
Sharon A. Newman, ${ }^{1,2}$ Sara A. Lincoln, ${ }^{1,3}$ Shane O'Reilly, ${ }^{1,4}$ Xiaolei Liu, ${ }^{1,5}$ Everett L. Shock, ${ }^{6-8}$ \\ Peter B. Kelemen, ${ }^{9}$ and Roger E. Summons ${ }^{1}$
}

\begin{abstract}
Serpentinization is a weathering process in which ultramafic rocks react with water, generating a range of products, including serpentine and other minerals, in addition to $\mathrm{H}_{2}$ and low-molecular-weight hydrocarbons that are capable of sustaining microbial life. Lipid biomarker analyses of serpentinite-hosted ecosystems hold promise as tools for investigating microbial activity in ancient Earth environments and other terrestrial planets such as Mars because lipids have the potential for longer term preservation relative to DNA, proteins, and other more labile organic molecules. Here, we report the first lipid biomarker record of microbial activity in the mantle section of the Samail Ophiolite, in the Sultanate of Oman, a site undergoing active serpentinization. We detected isoprenoidal (archaeal) and branched (bacterial) glycerol dialkyl glycerol tetraether (GDGT) lipids, including those with 0-3 cyclopentane moieties, and crenarchaeol, an isoprenoidal GDGT containing four cyclopentane and one cyclohexane moieties, as well as monoether lipids and fatty acids indicative of sulfatereducing bacteria. Comparison of our geochemical data and 16S rRNA data from the Samail Ophiolite with those from other serpentinite-hosted sites identifies the existence of a common core serpentinization microbiome. In light of these findings, we also discuss the preservation potential of serpentinite lipid biomarker assemblages on Earth and Mars. Continuing investigations of the Samail Ophiolite and other terrestrial analogues will enhance our understanding of microbial habitability and diversity in serpentinite-hosted environments on Earth and elsewhere in the Solar System. Key Words: Lipid biomarkers-Ophiolite-Serpentinization, BiosignaturesMars. Astrobiology 20, 830-845.
\end{abstract}

\section{Introduction}

T HE SEARCH FOR biosignatures on Mars and other terrestrial planets is aided by investigations of analog environments on Earth. Modern serpentinite-hosted ecosystems include both continental and marine settings, such as the Samail Ophiolite in the Sultanate of Oman (Miller et al., 2016; Canovas et al., 2017; Rempfert et al., 2017), the Tablelands Complex Ophiolite in Canada (Brazelton et al., 2012), and the Lost City Hydrothermal Field (LCHF) near the mid-Atlantic Oceanic Ridge (Kelley et al., 2005; Brazelton et al., 2006). These ecosystems are of significant scientific interest because serpentinization reactions are capable of supporting microbial metabolisms, and they are proposed to have played an important role in the origin and development of microbial life on Earth (Sleep et al., 2004; Schulte et al., 2006; Martin et al., 2008; Russell et al., 2010; McCollom and Seewald, 2013; Schrenk et al., 2013; Greenberger et al., 2015).

Serpentinization has long been hypothesized to occur on terrestrial planets, moons, and other celestial bodies throughout the Solar System (Holm et al., 2015). Most recently, a suite of minerals, including serpentine, Mg-carbonate, talc, and saponite, was detected on Mars by orbital spectral

\footnotetext{
${ }^{1}$ Department of Earth, Atmospheric and Planetary Sciences, Massachusetts Institute of Technology, Cambridge, Massachusetts.

${ }^{2}$ Division of Geological and Planetary Sciences, California Institute of Technology, Pasadena, California.

${ }^{3}$ Department of Geosciences, The Pennsylvania State University, University Park, Pennsylvania.

${ }_{5}^{4}$ School of Earth Sciences, University College Dublin, Belfield, Ireland.

${ }^{5}$ School of Geology and Geophysics, University of Oklahoma, Norman, Oklahoma.

${ }^{6}$ School of Earth and Space Exploration, Arizona State University, Tempe, Arizona.

${ }^{7}$ School of Molecular Sciences, Arizona State University, Tempe, Arizona.

${ }^{8}$ Center for Fundamental and Applied Microbiomics, Arizona State University, Tempe, Arizona.

${ }^{9}$ Lamont-Doherty Earth Observatory, Columbia University, Palisades, New York.
} 
imaging, and this suggests the occurrence of ancient serpentinization processes there (Ehlmann et al., 2009, 2010; Amador et al., 2017, 2018). Amador et al. (2018) used data from the Compact Reconnaissance Imaging Spectrometer for Mars (CRISM) to investigate the distribution of these minerals and olivine across the martian surface and near surface; several locations in the southern highlands, such as Nili Fossae, Mawrth Vallis, and Leighton Crater, were deemed regions of interest, but relationships between serpentine and ultramafic bedrock were only identified at Nili Fossae (Ehlmann et al., 2010; Amador et al., 2018). Nevertheless, the detection of serpentine exposures in the martian southern highlands suggests that serpentinization was likely a widespread process on early Mars (Ehlmann et al., 2010).

As we continue to explore the martian surface and subsurface with the current rover, Curiosity, and on future missions, it will be critical to determine whether and how serpentinite-hosted sites promote habitability and the preservation of biological signatures. These investigations can also inform decisions regarding the selection of future rover landing sites, as well as samples for return to Earth.

\subsection{Life fueled by serpentinization}

Serpentinization is a low-temperature, metamorphic process in which mafic and ultramafic rocks undergo hydrous alteration. During this reaction, reduced iron in olivine and pyroxene is oxidized through the reduction of water to produce serpentine and other minerals, as well as high concentrations of $\mathrm{H}_{2}$ and low-molecular-weight hydrocarbons (Neal and Stanger, 1983; Frost, 1985; Klein and Bach, 2009; Klein et al., 2009; McCollom and Bach, 2009; Miller et al., 2017; Mayhew et al., 2018), as in the following simplified reactions (Eqs. 1 and 2):

$$
\begin{aligned}
6 \mathrm{Fe}^{2+}{ }_{2} \mathrm{SiO}_{4(\text { olivine })} & +7 \mathrm{H}_{2} \mathrm{O} \rightarrow 3 \mathrm{Fe}^{2+}{ }_{3} \mathrm{Si}_{2} \mathrm{O}_{5}(\mathrm{OH})_{4(\text { serpentine })} \\
& +\mathrm{Fe}^{2+} \mathrm{Fe}^{3+}{ }_{2} \mathrm{O}_{4 \text { (magnetite) }}+\mathrm{H}_{2} .
\end{aligned}
$$

$$
\begin{aligned}
24 \mathrm{Fe}^{2+}{ }_{2} \mathrm{SiO}_{4} & +\mathrm{CO}_{2}+26 \mathrm{H}_{2} \mathrm{O} \rightarrow 12 \mathrm{Fe}^{2+}{ }_{3} \mathrm{Si}_{2} \mathrm{O}_{5}(\mathrm{OH})_{4} \\
& +4 \mathrm{Fe}^{2+} \mathrm{Fe}^{3+}{ }_{2} \mathrm{O}_{4}+\mathrm{CH}_{4} .
\end{aligned}
$$

Despite the high alkalinity and low inorganic carbon concentrations that are common in serpentinite-hosted ecosystems, the products of serpentinization reactions $-\mathrm{H}_{2}$ and methane-can provide substrates to sustain aerobic and anaerobic microbial metabolisms (McCollom and Seewald, 2013; Schrenk et al., 2013). Moreover, the reducing conditions that result from serpentinization can facilitate the microbial reduction of sulfate, which, in this case, uses hydrogen as an electron donor (Schrenk et al., 2013).

Metagenomic analyses of samples collected from a suite of modern serpentinite-hosted ecosystems on Earth point to the existence of a common core serpentinization microbiome (Woycheese et al., 2015). Clostridia, Bacteroidetes, and Betaproteobacteria are commonly found in serpentinitehosted ecosystems (Daae et al., 2013; Suzuki et al., 2013;
Tiago and Veríssimo, 2013; Quéméneur et al., 2015; Woycheese et al., 2015; Brazelton et al., 2017) and Methanobacterium, a methane-producing genus of archaea, is also frequently reported (Quéméneur et al., 2015; Woycheese et al., 2015; Brazelton et al., 2017). These findings, taken together with biological and biomolecular evidence, including the determination of isolate physiologies and transcriptomic and/or proteomic data (Canovas et al., 2017), suggest an association of microbial metabolisms such as hydrogen oxidation, sulfur cycling, methanotrophy, and methanogenesis with serpentinization processes (Woycheese et al., 2015).

Lipid biomarkers afford additional information regarding the microbial community composition at serpentinite-hosted sites because they typically reflect organic matter produced over a longer window of time relative to "snapshot" genetic surveys and can, thus, represent a cumulative record of biomass over time (Simoneit et al., 1998). The longevity of bacterial DNA is on the order of a few million years at most (Willerslev et al., 2004). Although the longevity of lipid biomarkers in serpentinite-hosted ecosystems has not been reported, these lipids can be sustained in carbonates (or carbonate-bearing sediments) for hundreds of millions of years or longer (Love et al., 2009; Saito et al., 2015, 2017). To identify the diversity of lipid biomarkers in serpentinitehosted ecosystems on Earth, several studies have recorded their distribution in marine hydrothermal systems and terrestrial seeps (Table 1) (Simoneit et al., 2004; Bradley et al., 2009a, 2009b; Méhay et al., 2013; Zwicker et al., 2018). For example, at the LCHF, the presence of archaeal glycerol dialkyl glycerol tetraethers (GDGTs) suggests the presence of Thaumarchaeota and Marine Group I-III archaea (Lincoln et al., 2013). The detection of archaeol in both active and inactive vents at the LCHF may suggest the presence of methanogenic archaea (Bradley et al., 2009b). Furthermore, the detection of glycerol mono- and diethers at the LCHF suggests the presence of sulfate-reducing bacteria (Bradley et al., 2009a, 2009b). The microbial community composition of the LCHF, as inferred from lipid assemblages, is largely consistent with DNA-based taxonomy (Kelley et al., 2005; Brazelton et al., 2006, 2012; Bradley et al., 2009a, 2009b; Lincoln et al., 2013).

\subsection{The Samail Ophiolite}

One of the largest $\left(>10,000 \mathrm{~km}^{2}\right)$, best exposed, and most widely studied serpentinite-hosted ecosystems on Earth is the mantle section of the Samail Ophiolite, located in the Hajar Mountains in the Sultanate of Oman and the United Arab Emirates (Glennie et al., 1974; Coleman and Hopson, 1981; Nicolas et al., 2000). This ophiolite, which formed 96-93 Ma (Tilton et al., 1991; Rioux et al., 2012, 2013, 2016), and was obducted onto the Arabian continental margin in the late Cretaceous (Coleman, 1981; Hacker, 1994; Rioux et al., 2016), contains a peridotite mantle composed primarily of olivine, orthopyroxene, and serpentine (Boudier and Coleman, 1981; Godard et al., 2000, 2003; Monnier et al., 2006; Tamura and Arai, 2006; Hanghøj et al., 2010). Low-temperature alteration of the peridotite, through interactions with groundwater and/or atmospheric $\mathrm{CO}_{2}$, has led to the precipitation of carbonate veins within the ophiolite's bedrock and calcite-rich 
Table 1. Current Record of Lipids Identified in Serpentinite-Hosted Ecosystems, Probable Source Microbes, and Associated Microbial Metabolisms

\begin{tabular}{|c|c|c|c|c|c|}
\hline $\begin{array}{l}\text { Lipids recorded } \\
\text { in Samail } \\
\text { Ophiolite } \\
\text { samples }\end{array}$ & $\begin{array}{l}\text { Lipids } \\
\text { reported } \\
\text { at the } \\
\text { LCHF }\end{array}$ & $\begin{array}{l}\text { Lipids } \\
\text { reported at } \\
\text { the Chimaera } \\
\text { Ophiolite }\end{array}$ & $\begin{array}{l}\text { Lipids } \\
\text { reported at } \\
\text { the Rainbow } \\
\text { Field }^{\mathrm{c}}\end{array}$ & $\begin{array}{l}\text { Probable source } \\
\text { microbes for lipids }\end{array}$ & $\begin{array}{l}\text { Associated processes/ } \\
\text { environmental } \\
\text { significance }^{\mathrm{d}}\end{array}$ \\
\hline $\begin{array}{l}\text { Isoprenoidal } \\
\text { GDGTs 0-4 }\end{array}$ & + & & & $\begin{array}{l}\text { Anaerobic methanotrophic archaea } \\
\text { (but also Crenarchaeota, Thaumarchaeota, } \\
\text { and methanogenic archaea) }\end{array}$ & Methanotrophy \\
\hline Crenarchaeol & + & & & Thaumarchaeota (e.g., Nitrososphaerales) & Nitrification \\
\hline Archaeol & + & + & & $\begin{array}{l}\text { Methanogenic archaea (e.g., } \\
\text { Methanobacterium) }\end{array}$ & Methanogenesis \\
\hline $\begin{array}{l}\text { Branched } \\
\text { GDGTs }\end{array}$ & + & & & $\begin{array}{l}\text { Soil microbes (e.g., Acidobacteria), } \\
\text { unknown sources }\end{array}$ & Unknown \\
\hline $\begin{array}{l}\text { Glycerol } \\
\text { monoethers } \\
\text { (MAGE) }\end{array}$ & + & + & & $\begin{array}{l}\text { Sulfate-reducing bacteria (e.g., Firmicutes, } \\
\text { Thermodesulfovibrionaceaea) }\end{array}$ & Sulfate reduction \\
\hline Fatty acids & + & & + & $\begin{array}{l}\text { Sulfate-reducing bacteria (e.g., Firmicutes, } \\
\text { Thermodesulfovibrionaceaea) }\end{array}$ & Sulfate reduction \\
\hline 1,2-Alkyl diols & & & & Nonmarine alkaliphilic bacteria & $\begin{array}{c}\text { Thermal/alkaline } \\
\text { environments }\end{array}$ \\
\hline
\end{tabular}

(+) denotes lipid is present at serpentinite-hosted ecosystem; blank spaces denote lipid was not measured and/or discussed in the literature.

${ }^{a}$ References for lipids found at the LCHF, Mid-Atlantic Oceanic Ridge: Bradley et al. (2009b), Lincoln et al. (2013), and Méhay et al. (2013).

${ }^{\mathrm{b}}$ Reference for lipids found at the Chimaera Ophiolite, Turkey: Zwicker et al. (2018).

${ }^{c}$ Reference for lipids found at the Rainbow Field, Mid-Atlantic Ridge: Simoneit et al. (2004).

${ }^{\mathrm{d}}$ Refer to in-text citations for associated references.

GDGT, glycerol dialkyl glycerol tetraether; LCHF, Lost City Hydrothermal Field; MAGE, monoalkyl glycerol monoethers.

travertines at its surface (Neal and Stanger, 1983, 1985; Clark and Fontes, 1990; Kelemen and Matter, 2008; Kelemen et al., 2011); ${ }^{14} \mathrm{C}$ dating and stable $\mathrm{C}$ and $\mathrm{O}$ isotopic analyses suggest that these alteration products formed within the past 50,000 years (Kelemen and Matter, 2008; Mervine et al., 2014).

At the ophiolite, active serpentinization is inferred from

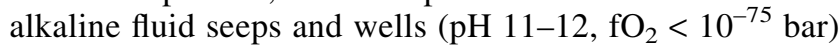
(Barnes et al., 1978; Neal and Stanger, 1983; Kelemen et al., 2018) containing high concentrations of $\mathrm{Ca}^{2+}, \mathrm{H}_{2}$, and $\mathrm{CH}_{4}[\leq 2.18 \mathrm{mM}, \leq 321.27 \mu \mathrm{M}$, and $\leq 131.62 \mu \mathrm{M}$, respectively, Canovas et al. (2017); see also Schrenk et al. (2013); Paukert Vankeuren et al. (2019)], and low concentrations of dissolved inorganic carbon $(\leq 5.17 \mathrm{mM}$ ) (Canovas et al., 2017). Host rocks have gradients in vein area and vein type related to the current erosional surface, indicative of ongoing weathering, and they contain highly reduced $\mathrm{Fe}-\mathrm{Ni}-\mathrm{Cu}-\mathrm{S}$ minerals preserving $\mathrm{fO}_{2}<10^{-70}$ bar, consistent with the composition of present-day borehole fluids (Lorand, 1988; Eslami et al., 2018; Kelemen et al., 2018). All of these characteristics are consistent with geochemical models of serpentinization (Barnes et al., 1978; Bruni et al., 2002; Paukert et al., 2012), and with the inference that serpentinization is ongoing.

To date, only a few studies have investigated microbial diversity at the Samail Ophiolite (e.g., Bath et al., 1987; Miller et al., 2016; Rempfert et al., 2017; Fones et al., 2019). Miller et al. (2016) collected samples from wells drilled into peridotite in the mantle section of the ophiolite and found $16 \mathrm{~S}$ rDNA evidence for the presence of sulfate reducing taxa (e.g., Meiothermus and Thermodesulfovibrionaceaea), methane-producing archaea (e.g.,
Methanobacterium sp.), and methane oxidizing bacteria (e.g., Methylococcales). Despite the utility of molecular biogeochemical research, there has been limited investigation of the lipid biomarker record at terrestrial serpentinite-hosted sites.

In this study, we investigate the lipid biomarker record from the carbonate veins and travertines at the Samail Ophiolite in Oman. Based on lipid biomarker assessments from the LCHF and other serpentinite-hosted ecosystems (Bradley et al., 2009a, 2009b; Zwicker et al., 2018), we expected to find a similarly diverse lipidome at the Samail Ophiolite. Specifically, we report distributions of membranespanning isoprenoidal (archaeal) and branched (bacterial) GDGTs, as well as monoalkyl glycerol monoethers (MAGE) and fatty acids, considered to be derived from sulfatereducing bacteria.

\section{Materials and Methods}

\subsection{Sample collection, preparation, and $X$-ray diffraction}

Samples were collected in 2012 from vein carbonates, travertines, and host rocks in the Samail Ophiolite in the Oman mountains, located in the Sultanate of Oman (Fig. 1, Table 2, and Supplementary Fig. S1). These were broken from outcrops with a hammer, untouched, and double wrapped in aluminum foil at each site of sampling to minimize contamination. In the laboratory, samples were first cleaned with deionized water and ground into a fine powder with a puck and mill. The mineral composition of each sample was evaluated by powdered X-ray diffraction (XRD) analysis on a PANalytical X'Pert Pro XRPD (PANalytical, 


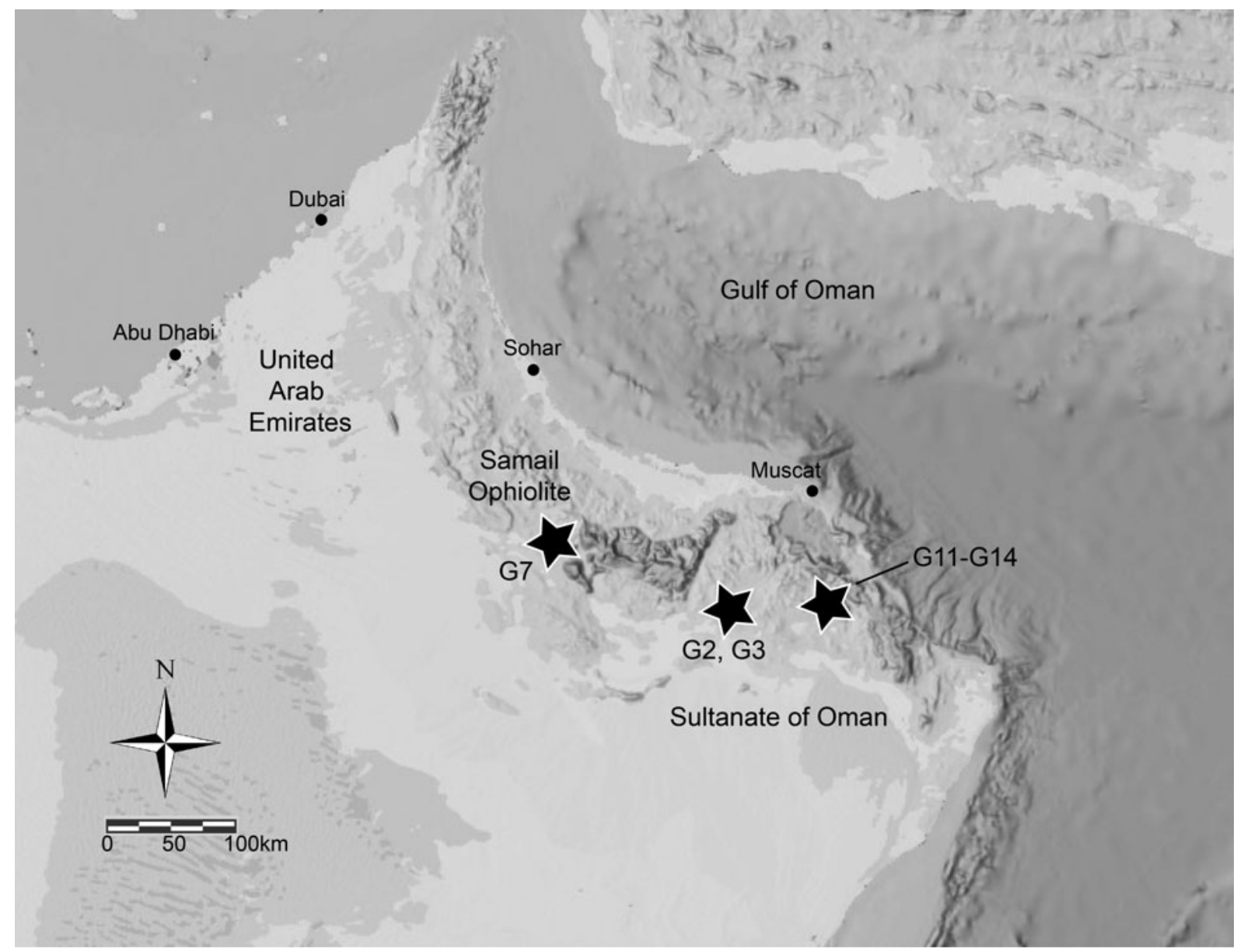

FIG. 1. Samail Ophiolite field locations (stars), where samples G2-G14 were collected. Map was generated using ArcGIS Online. Sources: Esri, HERE, Garmin, FAO, NOAA, USGS. HERE, HERE Technologies; FAO, Food and Agriculture Organization; NOAA, National Oceanic and Atmospheric Administration; USGS, United States Geological Survey.

Almelo, the Netherlands) at the Center for Materials Science and Engineering at MIT (Cambridge, MA). XRD spectra were collected from $5^{\circ}$ to $90^{\circ}$ and analyzed with the computer software program HighScore Plus (Malvern Panalytical, Malvern, United Kingdom). Samples were categorized into subsets $\mathrm{A}$ and $\mathrm{B}$, according to mineral composition and biomarker distribution (see Section 3).

\subsection{Lipid extraction}

Before solvent extraction, powdered samples were spiked with $1 \mu \mathrm{g}$ of the following quantification standards: 3methylheneicosane and epiandrosterone. All samples were ultrasonically extracted three times with dichloromethane (DCM):methanol $(\mathrm{MeOH}), 9: 1(\mathrm{v} / \mathrm{v})$. Samples were then

Table 2. List of Samail Ophiolite Samples Collected and Analyzed With Corresponding Site Descriptions and GPS UTM CoORdinates

\begin{tabular}{|c|c|c|c|c|c|}
\hline \multirow{2}{*}{$\begin{array}{l}\text { Sample } \\
\text { subset }\end{array}$} & \multirow{2}{*}{$\begin{array}{c}\text { Sample } \\
\text { name }\end{array}$} & \multirow[b]{2}{*}{ Sample description } & \multirow[b]{2}{*}{ Carbonate phase(s) present ${ }^{\mathrm{a}}$} & \multicolumn{2}{|c|}{$\begin{array}{c}\text { GPS coordinates } \\
\text { (WGS84, UTM zone 40) }\end{array}$} \\
\hline & & & & Easting & Northing \\
\hline \multirow[t]{3}{*}{ Subset A } & G2 & $\begin{array}{l}\text { Layered carbonate } \sim 20 \mathrm{~cm} \text { above } \\
\text { ultramafic contact }\end{array}$ & Aragonite, calcite, dolomite & 0608435 & 2525955 \\
\hline & G3 & Carbonate at ultramafic contact & Calcite, dolomite & 0608435 & 2525955 \\
\hline & G7 & Apron travertine down flow from pool & Calcite & 0487340 & 2576126 \\
\hline \multirow[t]{4}{*}{ Subset B } & G11 & Carbonate vein in what might be dunite & Aragonite, calcite, magnesite & 0675494 & 2529793 \\
\hline & G12 & Host rock for G11 & Calcite & 0675494 & 2529793 \\
\hline & G13 & Carbonate vein in peridotite & $\begin{array}{l}\text { Aragonite, calcite, dolomite, } \\
\text { magnesite }\end{array}$ & 0675494 & 2529793 \\
\hline & G14 & Host rock for G13 & Dolomite & 0675494 & 2529793 \\
\hline
\end{tabular}

${ }^{a}$ Carbonate phases were identified by X-ray diffraction (see Section 2).

GPS, Global Positioning System; WGS84, World Geodetic System; UTM, Universal Transverse Mercator System. 
centrifuged at 3,000 rpm for $30 \mathrm{~min}$, and extracts from each sample were combined and concentrated to a small volume $(<1 \mathrm{~mL})$ by using $\mathrm{N}_{2}$. The total lipid extract (TLE) was then passed through filter columns (containing combusted sodium sulfate and sand) to remove particulate impurities. Copper pellets (activated with $12 \mathrm{~N} \mathrm{HCl}$, neutralized with DCM-washed water, and then washed $3 \times$ with $\mathrm{MeOH}$, DCM, and hexane) were added to the TLEs and left overnight to facilitate the removal of elemental sulfur. The TLEs were filtered through a second pipette column packed with quartz wool and transferred to $2 \mathrm{~mL}$ GC vials with inserts. Due to limited sample volume and low lipid recovery for some samples, compound-specific isotopic analyses were not performed.

\subsection{Gas chromatography-mass spectrometry}

An aliquot (33.3\%) of each TLE was transferred into a 2$\mathrm{mL}$ vial, dried with $\mathrm{N}_{2}$, and finally derivatized with $50 \mu \mathrm{L}$ $\mathrm{N}, \mathrm{O}$-bis(trimethylsilyl) trifluoro-acetamide (BSTFA $+1 \%$ trimethylchlorosilane) and $50 \mu \mathrm{L}$ pyridine at $60^{\circ} \mathrm{C}$ for $30 \mathrm{~min}$. A total of $1 \mu \mathrm{L}$ aliquots were injected in splitless mode to an Agilent 7890A gas chromatograph coupled to an Agilent 5975C mass spectrometer (GC-MS). Separation of compounds was achieved by using a DB5-MS capillary column $(60 \mathrm{~m} \times 0.25 \mathrm{~mm}, 0.25 \mu \mathrm{m}$ film thickness; Agilent, Santa Clara, CA). Initial temperature of the column was set to $70^{\circ} \mathrm{C}$, followed by a ramp of $10^{\circ} \mathrm{C} / \mathrm{min}$ until a maximum oven temperature of $325^{\circ} \mathrm{C}$ was reached. Concentrations of fatty acids and alkyl diols were determined by using the internal standard, 3-methylheneicosane; concentrations of MAGE were determined by using the internal standard, epiandrosterone. Additional rock material from samples G11 and G13 was solvent extracted, using the same methods as described in section 2.2, and the positions of fatty acid unsaturations were determined by dimethyl disulfide adduction (see Nichols et al., 1986; O'Reilly et al., 2017, their supporting methods).

\subsection{High-performance liquid chromatography}

One-third of each TLE sample was analyzed with highperformance liquid chromatography-MS on an Agilent 1260 Infinity series LC coupled to a 6130 quadrupole mass spectrometer via an atmospheric pressure chemical ionization (APCI) interface in positive mode. Samples were measured by selected ion monitoring (SIM) and separated with two Acquity UPLC BEH HILIC Amide columns $(2.1 \times 150 \mathrm{~mm}, 1.7 \mu \mathrm{m}$; Waters, Milford, MA) maintained at $50^{\circ} \mathrm{C}$. The method was adapted from the work of Becker et al. (2013), and the sample injection volume was $10 \mu \mathrm{L}$. Using a constant flow rate of $0.5 \mathrm{~mL} / \mathrm{min}$, we eluted the samples with a solvent gradient program of a linear change from $3 \% \mathrm{~B}$ to $20 \% \mathrm{~B}$ in $20 \mathrm{~min}$, then a linear increase to $50 \% \mathrm{~B}$ at $35 \mathrm{~min}$, and a linear increase to $100 \% \mathrm{~B}$ at $45 \mathrm{~min}$, holding for $6 \mathrm{~min}$, and then a decrease to $3 \% \mathrm{~B}$ for 9 min to re-equilibrate the column, where A was $n$-hexane and B was $n$-hexane/isopropanol (90:10). APCI source conditions were positive ion mode, drying gas $\left(\mathrm{N}_{2}\right)$ temperature $350^{\circ} \mathrm{C}$, vaporizer temperature $380^{\circ} \mathrm{C}$, drying gas flow rate $6 \mathrm{~L} / \mathrm{min}$, nebulizer gas $\left(\mathrm{N}_{2}\right)$ pressure $30 \mathrm{psi}$, capillary voltage $2000 \mathrm{~V}$, and corona current $5 \mu \mathrm{A}$. GDGTs were detected by both full scans and SIM, and they were quantified by $[\mathrm{M}+\mathrm{H}]^{+}$(where $\mathrm{M}$ is the molecular ion) with an extraction window of individual ion chromatograms. Samples were spiked with $\mathrm{C}_{46}$ GTGT (glycerol trialkyl glycerol tetraether) to determine the concentration of GDGTs (Huguet et al., 2006).

\section{Results}

\subsection{Carbonate mineralogy}

XRD analyses were conducted to determine the mineral composition of the Samail Ophiolite samples. Layered carbonate and travertine samples (G2, G3, and G7) were composed of magnesian calcite (Table 2 and Supplementary Fig. S2), and samples G2 and G3 also contained aragonite and/or dolomite. Magnesite was found exclusively in vein samples (G11 and G13), which were also composed of magnesian calcite and aragonite; dolomite was also present in sample G13. Host rock samples (G12 and G14) contained either calcite or dolomite (Table 2). See Supplementary Fig. S2 for a list of all minerals found in Samail Ophiolite samples.

\subsection{Isoprenoidal glycerol tetraethers}

Isoprenoidal GDGTs (iGDGTs; see Fig. 2 for lipid structures), which include GDGTs $0-4$ with 0 to 4 moieties, and crenarchaeol (and its putative regio-isomer) with four cyclopentane moieties and one cyclohexane moiety were found in all solvent extracted samples, with the highest concentrations measured at $2 \mathrm{ng} / \mathrm{g}$ of dried rock (Fig. 3 and Supplementary Table S1). We categorize our samples into two main groups, based on ratios of GDGT-0/crenarchaeol: GDGT-0 was the dominant iGDGT in all subset A samples (G2, G3, and G7), which is reflected by high ratios of GDGT-0/crenarchaeol (1.3-5.0; Fig. 3, Supplementary Fig. S3, and Supplementary Table S1). In contrast, crenarchaeol was the dominant iGDGT in all subset B samples (G11, G12, G13, and G14), with comparatively lower ratios of GDGT-0/crenarchaeol (<1, Fig. 3, Supplementary Fig. S3, and Supplementary Table S1).

\subsection{Branched glycerol tetraethers}

Branched GDGTs (brGDGTs; see Fig. 2 for lipid structures) were present in all samples and included brGDGTs I, II, and III, which contain methyl substituents and no cyclopentane moieties, and brGDGTs Ib-IIIb, and Ic-IIIc with one or two cyclopentane moieties, respectively, and their methylated substituents. Concentrations of brGDGTs ranged up to $10 \mathrm{ng} / \mathrm{g}$ of dried rock, and brGDGT I, II, and III were the most highly concentrated in all samples relative to brGDGTs with cyclopentane substituents (Fig. 3 and Supplementary Table S1).

\subsection{Archaeol}

Archaeol, an isoprenoidal diether lipid (see Fig. 2 for lipid structure), was also present in all samples with the exception of G14. This lipid had the highest concentrations in subset A samples $(40,1$, and $1 \mathrm{ng} / \mathrm{g}$ of dried rock in G2, G3, and G7, respectively) relative to subset $B$ samples $(<1 \mathrm{ng} / \mathrm{g}$ of dried rock in G11, G12, and G13) (Fig. 3 and Supplementary Table S1). 


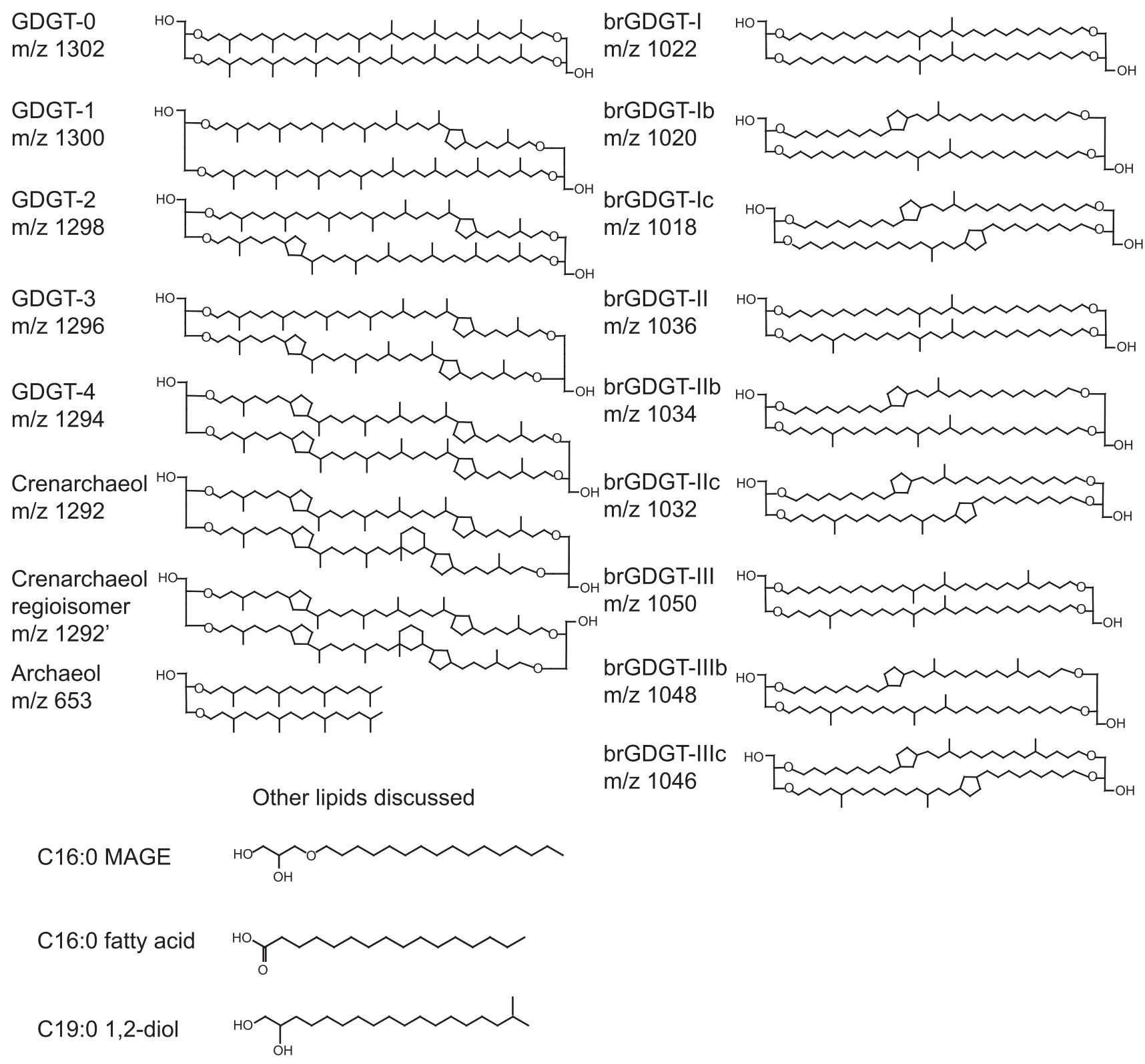

FIG. 2. Structures of lipid biomarkers detected at the Samail Ophiolite and discussed in the text. Isoprenoidal and branched tetra- and diether lipids are shown, as well as representative structures of a derivatized monoether, fatty acid, and alkyl diol.

\subsection{Monoalkyl glycerol monoethers}

Samples G2 through G13 contained a suite of MAGE lipids (see Fig. 2 for representative lipid structure) with $\mathrm{C}_{15}$ through $\mathrm{C}_{18}$ straight-chain, branched, and monosaturated hydrocarbons. MAGE were identified based on the characteristic base peak at $\mathrm{m} / \mathrm{z} 205$, which is produced from cleavage between $\mathrm{C} 1$ and $\mathrm{C} 2$ of the glycerol for trimethylsilyl (TMS) ether derivatives. Other characteristic ions include $\mathrm{m} / \mathrm{z} 117,147,130,133,[\mathrm{M}-15]^{+},[\mathrm{M}-90]^{+}$, and $[\mathrm{M}-103]^{+}$(Hernandez-Sanchez et al., 2014; Grossi et al., 2015; Wang and $\mathrm{Xu}, 2016$ ). MAGE isomers were also identified according to the characteristic elution orders for saturated, monounsaturated, and methyl-branched isomers on nonpolar GC columns. $\mathrm{C}_{16: 0}$ and $\mathrm{C}_{18: 0}$ MAGE were most abundant throughout all samples, ranging in mass up to 13 and $11 \mathrm{ng}$ of lipid/g of dried rock, respectively (found in sample G13; Supplementary Table S2).

\subsection{Fatty acids}

Unesterified fatty acids (see Fig. 2 for representative lipid structure) were present in all samples, and they were identified as TMS derivatives with a characteristic fragment ion at $m / z 117$, as well as by comparison to the NIST database 


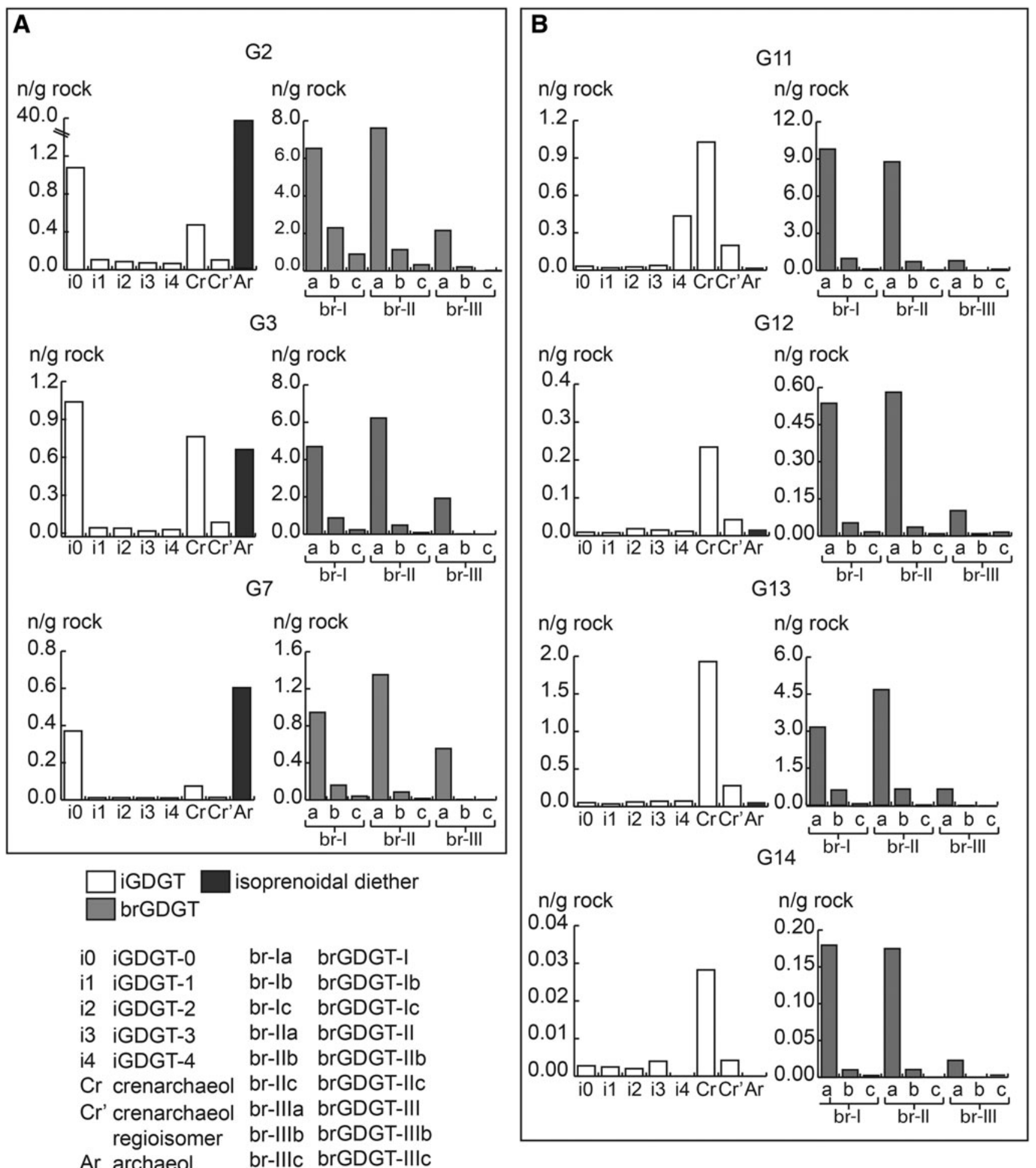

FIG. 3. iGDGT, brGDGT, and archaeol concentrations in (A) subset A (G2-G7) and (B) subset B (G11-G14) Samail Ophiolite samples. GDGT, glycerol dialkyl glycerol tetraether; brGDGT, branched GDGT; iGDGT, isoprenoidal GDGT.

(National Institute of Standards and Technology, Gaithersburg, MD). Positions of fatty acid unsaturation were identified for samples G11 and G13 (see Section 2), and the locations of unsaturation for the other samples were determined by comparison of relative retention times. Samples G2 and G13 contained the greatest abundance and most diverse suite of fatty acids per gram of dried rock (i.e., $\mathrm{C}_{10}$ through $\mathrm{C}_{30}$ saturated, unsaturated, branched, and straightchain fatty acids) relative to the other samples (Supplementary Table S3). Concentrations of fatty acids ranged from below detection to $299 \mathrm{ng} / \mathrm{g}$ of dried rock (Supplementary Table S3). Across all samples, $\mathrm{C}_{16}$ and $\mathrm{C}_{18}$ straight-chain saturated fatty acids were the most abundant, ranging up to 222 and $147 \mathrm{ng} / \mathrm{g}$ of dried rock, respectively 
(for sample G13; Supplementary Table S3). Methylbranched fatty acids were identified in all samples with the exception of G14, but they were only detected in appreciable amounts in G2, G11, and G13 (Supplementary Table S3). Carbon chain lengths ranged from 10 to 25 and the most commonly identified branching positions were at the iso $(\omega-1)$ and anteiso $(\omega-2)$ positions. Monounsaturated fatty acids were detected in trace amounts in all samples apart from G13. The major monounsaturated fatty acids were $\mathrm{C}_{16}$ and $\mathrm{C}_{18}$ with $\omega 9$ and $\omega 7$ unsaturations (Supplementary Table S3).

\subsection{Alkyl diols}

A series of 1,2-alkyl diols (see Fig. 2 for representative lipid structure) were detected in the Samail Ophiolite samples and identified by comparison with published spectra (Zeng et al., 1992; Wait et al., 1997) (Supplementary Table S4). Carbon chain lengths ranged from 18 to 20, and hydroxyl moieties were located at positions 1 and 2 on the carbon chain. All 1,2-alkyl diols contained methyl branches that were likely at the 2- and 3-positions (Wait et al., 1997) but, in the absence of authentic standards, could not be established with certainty. The overall highest concentrations of 1,2-alkyl diols were found in samples G11 and G13, with values ranging in each sample from 2 to 12 and 9 to $48 \mathrm{ng} / \mathrm{g}$ of dried rock, respectively (Supplementary Table S4). Relatively lower concentrations of 1,2-alkyl diols were present in samples G2 and G12, with values ranging from 1 to 6 and 1 to $3 \mathrm{ng} / \mathrm{g}$ of dried rock, respectively (Supplementary Table S4). Only two 1,2-alkyl diols were detected in sample G3 (17-methyloctadecan-1,2-diol and 18-methylnonadecan1,2-diol), and these were also found in low concentrations (up to $3 \mathrm{ng} / \mathrm{g}$ of dried rock); 1,2-alkyl diols were absent from samples G7 and G14 (Supplementary Table S4).

\section{Discussion}

\subsection{Potential sources of lipid biomarkers in the Samail Ophiolite samples}

4.1.1. Isoprenoidal glycerol tetraethers. The distribution of iGDGTs in subset A samples (G2, G3, and G7) (Fig. 3 and Supplementary Table S1) is typical of those found in low-temperature marine sediments, which are dominated by both GDGT-0 and crenarchaeol (Schouten et al., 2002) and reflect a substantial contribution from Thaumarchaeota. These ammonia-oxidizing archaea have been shown to fix inorganic carbon in culture (Könneke et al., 2005). Additional sources of iGDGT 0-4 in these samples likely include Crenarchaeota (Thurl and Schäfer, 1988; Trincone et al., 1992; Völkl et al., 1993; Boyd et al., 2011) and methanotrophic Euryarchaeota (Pancost et al., 2001; Zhang et al., 2003; Blumenberg et al., 2004). For all samples in subset B (G11, G12, G13, and G14), crenarchaeol was the dominant iGDGT, and it comprised $>65 \%$ of all iGDGTs in these carbonates (Fig. 3 and Supplementary Table S1). This distribution is characteristic of alkaline soil environments (Weijers et al., 2006), and iGDGTs found in subset B samples may reflect substantial contributions from soil Thaumarchaeota and/or other terrestrial archaeal species.

At the LCHF (an oceanic setting, devoid of terrestrial soil input), the co-occurrence of crenarchaeol and nucleic acids of Marine Group I Thaumarchaeota indicates a likely productsource relationship between the two (Lincoln et al., 2013, 2014). Rempfert et al. (2017) reported ribosomal DNA sequences for Thaumarchaeota in some Samail Ophiolite well samples, supporting the identification of these archaea as the primary source of crenarchaeol in this study. Cultivated members of the phylum Thaumarchaeota are capable of ammonia oxidation (Könneke et al., 2005), and amoA, the gene that codes for this metabolic process, has been correlated with Thaumarchaeotal abundance and crenarchaeol concentrations (Leininger et al., 2006). Concentrations of total ammonia in Samail Ophiolite hyperalkaline spring waters have been shown to range up to $0.12 \mathrm{mM}$, but these values may be considerably lower in surface waters (Canovas et al., 2017) [ammonia concentrations in endmember fluids at the LCHF are less than $6 \mu \mathrm{M}$ (Lang et al. 2013)]. This may be adequate to support Thaumarchaeota because isolates such as Nitrosopumilus maritimus are known to grow under ammonia limitation due to their high substrate affinity for ammonia (Martens-Habbena et al., 2009). Moreover, Canovas et al. (2017) demonstrated that there is a substantial energy supply from ammonia oxidation in fluids from the Samail Ophiolite.

Differences in the distribution of iGDGTs across samples (Fig. 3 and Supplementary Table S1) can be explained by the environments in which these samples were formed (Table 2 and Supplementary Fig. S2). The travertine and layered carbonates (subset A samples) were composed of calcite, dolomite, and aragonite, which suggests that these may have originated from the surface outflow of serpentinized fluids that were rich in $\mathrm{Ca}^{2+}$ and $\mathrm{OH}^{-}$(Kelemen and Matter, 2008; Paukert et al., 2012). In contrast, magnesite was found exclusively in vein samples (G11 and G13), and this mineral was likely formed by interactions between peridotite and meteoric or surface waters in subsurface environments (Neal and Stanger, 1985; Kelemen and Matter, 2008; Paukert et al., 2012). Surface and subsurface habitats differ in composition, water:rock ratios, and state of reaction progresses, and this may account for some of the differences observed between sample subsets. Although sample mineral composition may have also played a role in the preservation of iGDGTs, we were unable to identify specific mineralogical effects unrelated to the environment of sample formation (surface vs. subsurface) or type of sample (travertine, vein, host rock, etc.). Moreover, it is likely that the lipid biomarker record presented here reflects contributions from both modern, endolithic microbes and microbial activity at the time of carbonate formation. Microbial communities that were present during early carbonate formation likely depended on fundamentally different metabolic strategies relative to modern endolithic microbes at Oman, and this may also contribute to variations in iGDGT distributions observed in the current study.

4.1.2. Branched glycerol tetraethers. Initially, brGDGTs were considered to be exclusively of nonmarine origin because these lipids are frequently found in soil and peat bogs, and they are associated with the presence of Acidobacteria (Weijers et al., 2009). However, brGDGTs have also been found in marine (Peterse et al., 2009) and lacustrine (Sinninghe Damsté et al., 2009; Tierney and Russell, 2009; Tierney et al., 2010) environments, suggesting a more global 
distribution for these lipids. In this study, we suggest that brGDGTs in subset A samples are likely derived from nonsoil sources, whereas brGDGTs in subset B samples are likely synthesized by soil bacteria (see discussion on iGDGTs and alkyl diols for additional differences between sample subsets). BrGDGTs have also been found in marine hydrothermal systems such as the LCHF (Lincoln et al., 2013), the Southwest Indian Ridge [Eastern Pacific Ocean; Pan et al. (2016)], and the southern Mid-Atlantic Ridge (Li et al., 2018), providing additional evidence for the widespread production of these lipids, though their specific sources are not currently known.

4.1.3. Archaeol. The presence of archaeol in six of our seven samples is consistent with a scenario of methanogenesis at the Samail Ophiolite. Indeed, the methane-producing archaeon, Methanobacterium, has been reported in subsurface fluids at the ophiolite (Miller et al., 2016; Rempfert et al., 2017 ) in conjunction with methane concentrations of up to 4.3\% volume (Schrenk et al., 2013). Moreover, the elevated ratios of GDGT-0/crenarchaeol in subset A samples may suggest methanogenic activities (Pan et al., 2016). However, archaeol can also be synthesized by a variety of nonmethanogenic archaea, including anaerobic methane oxidizers, halophiles, miscellaneous Crenarchaeota (Koga and Morii, 2005; Lipp and Hinrichs, 2009), and Thaumarchaeota (Elling et al., 2017), and abiogenic processes, such as Fischer-Tropsch and Sabatier reactions, can also contribute to methane generation (Etiope and Sherwood Lollar, 2013; Etiope, 2017). Thus, the origin of methane at the Samail Ophiolite, as in other serpentinizing environments, remains poorly constrained.

Isotopic compositions of methane at the ophiolite provide no clear clues to its source. Miller et al. (2016) reported methane greatly enriched in ${ }^{13} \mathrm{C}$ in Samail Ophiolite fluids, outside previously defined ranges for biogenic, abiotic, and thermogenic methane. They discuss explanations for extreme carbon isotopic enrichment that do not exclude a biological origin, including carbon limitation. Alternatively, methane may be formed through low-temperature abiological processes that use chromitite or ruthenium as a catalyst (Etiope and Sherwood Lollar, 2013). Future work investigating the carbon isotopic composition of archaeol, as well as other lipids not identified in the current set of samples, but associated with both methanogenesis and serpentinization processes [e.g., isoprenoidal diethers; Bradley et al. (2009b)], would enhance our understanding of methane production at the Samail Ophiolite and in analog serpentinite-hosted ecosystems.

4.1.4. MAGE and fatty acids. MAGE with varying saturated and unsaturated $\mathrm{C}_{15}-\mathrm{C}_{18}$ side chains are believed to be primarily derived from sulfate-reducing bacteria (Langworthy et al., 1983; Rütters et al., 2001; Vinçon-Laugier et al., 2016, 2017), even though they have also been recorded in a number of other bacterial taxa (Grossi et al., 2015; Yang et al., 2015). Hernandez-Sanchez et al. (2014) demonstrated that branched MAGE are commonly found in suboxic/anoxic marine sediments, whereas water column particulates typically contain lower relative abundances. Iso-, anteiso-, and mid-chain methyl branched fatty acids are also present in our samples, and they are similarly attributed to sulfate-reducing bacteria. However, numerous other taxa could also contribute to these fatty acids (O'Reilly et al., 2017). Nevertheless, $16 \mathrm{~S}$ rRNA data have demonstrated the universality of sulfur cycling bacteria, for example, Desulfonatronum, Thiobaccilus, and Firmicutes, at serpentinite-hosted ecosystems (Daae et al., 2013; Woycheese et al., 2015), and lipid evidence for sulfate reduction at other serpentinite-hosted ecosystems has been reported (Bradley et al., 2009b; Klein et al., 2015). The occurrence of Thermodesulfovibrionaceae, a family of sulfate-reducing bacteria, at the Samail ophiliolite (Miller et al., 2016; Rempfert et al., 2017) may suggest a contribution of sulfate-reducing bacteria to MAGE and fatty acid production in our samples.

4.1.5. Alkyl diols. Relatively high concentrations of 1,2alkyl diols were restricted to subset B samples (i.e., G11 and G13). 1,2-alkyl diols are rarely reported in environmental samples and based on evidence at present appear to be restricted to thermal and/or alkaline spring environments (Zeng et al., 1992; Pancost et al., 2005) and cultures of thermophilic bacteria (Pond et al., 1986; Wait et al., 1997; Van der Meer et al., 2002). If our interpretation of the iGDGT distribution in our samples is correct, then the high occurrence of 1,2-alkyl diols in subset B samples may originate from nonmarine alkaliphilic bacteria. However, a higher plant signal cannot be ruled out (Buschhaus et al., 2013).

4.1.6. Potentially diagnostic lipids not reported in the current study. Due to the limited sample volume and low recovery of some lipids (see Section 3), we did not screen for bacteriohopanepolyols (BHPs), which can be synthesized by methanotrophic bacteria (Talbot et al., 2001; van Winden et al., 2012), methanogen-derived hydroxyarchaeol (Koga et al., 1993), and intact polar lipids (IPLs). IPLs, in particular, are prone to rapid degradation during early diagenesis, and although these lipids can aid in the characterization of living microbial communities, their utility in the reconstruction of ancient records is, at best, limited (e.g., Logemann et al., 2011). Despite the absence of data on BHPs, hydroxyarchaeol, and IPLs in this study, we do not rule out the possibility of the presence of these lipids in the Samail Ophiolite samples, and the potential for their inclusion in the serpentinization lipidome (Table 1). Moreover, we did not detect steroid biomarkers in the Samail Ophiolite samples, but we suggest that these may also be important lipids at other serpentinite-hosted ecosystems.

4.1.7. Summary of lipid biomarkers and their sources. We categorize the Samail Ophiolite samples into two distinct subsets, as determined by sample mineralogies and lipid biomarker distributions. Subset A samples were likely formed in serpentinite-hosted surface environments and record lipids derived primarily from marine microorganisms; subset B samples were likely formed in subsurface environments due to interactions with surface waters and record lipids derived primarily from soil bacteria and other terrestrial sources. The presence of archaeol in subset A samples, in addition to elevated GDGT-0/crenarchaeol ratios, may suggest active methanogensis at the Samail Ophiolite. This is 
consistent with rRNA evidence of methane-producing archaea there (Miller et al., 2016). The presence of MAGE and fatty acids in these samples likely suggests the occurrence of sulfate-reducing bacteria at the ophiolite.

\subsection{Implications for the preservation and detection of lipids in ancient environments on Mars}

This study reconstructs microbial activity in a modern serpentinite-hosted ecosystem on Earth as inferred from the lipid biomarker record of recently formed carbonates ( $<50,000$ years) (Kelemen and Matter, 2008; Kelemen et al., 2011; Mervine et al., 2014). Lipids present in the Samail Ophiolite samples that are consistent with rRNA results, such as crenarchaeol (likely derived from Thaumarchaeota), archaeol (possibly derived from archaea of the class Methanobacteria), and fatty acids and monoethers (likely derived from sulfate-reducing bacteria), may have been formed by modern and/or recent microbial activity. Lipid synthesis during early carbonate formation $(\sim 50,000 \mathrm{ka})$ likely also contributed to the total lipid reservoir at Oman, though relative contributions from modern and ancient sources cannot be constrained by the methods used in this study. However, if lipid biomarkers are, indeed, preserved on Mars, they were likely produced billions of years ago, during the Noachian and/or Hesperian Periods (4.1-3.7 and 3.7-3.0 Gyr, respectively) because the warmer and wetter climate during these Periods (Cabrol and Grin, 1999; Moore and Howard, 2005; Fassett and Head, 2008; Warner et al., 2010; Andrews-Hanna and Lewis, 2011; Ehlmann et al., 2011; Halevy and Head, 2014; Goudge et al., 2016) may have supported microbial life (Cabrol and Grin, 1999; Warner et al., 2010; Ehlmann et al., 2011). Thus, the implications of this study for the detection of lipid biomarkers in ancient environments on Earth and Mars are discussed next.

An important consideration in the search for ancient biosignatures is the potential of these molecules for longterm preservation. Although the preservation potential of the serpentinization lipidome remains poorly constrained, evidence from the sedimentary rock record on Earth suggests that the long-term preservation of lipids is a common occurrence. The earliest reported evidence of ether lipids on Earth, which includes archaeol, non-isoprenoidal monoethers and diethers, and their diagenetic products (biphytanes), is from the early to mid-Triassic (Saito et al., 2015, 2017) and the late Carboniferous (Birgel et al., 2008). However, laboratory studies have demonstrated the ability of these archaeal lipids to tolerate high levels of thermal maturation (Koopmans et al., 1995, 1996; Pease et al., 1998), highlighting their potential for even longer-term preservation than has been previously reported (Saito et al., 2015, 2017). This, combined with the ability of some archaea to tolerate extreme environmental conditions, such as exposure to UV radiation and perchlorates (Oren, 2014; see later discussion in section 4.2), make archaeal lipids excellent candidates for detection on Mars. Moreover, slower weathering rates on Mars relative to Earth and conditions of rapid organic burial (Hays et al., 2017) would likely facilitate the long-term preservation of archaeal lipids if, in fact, they were produced on Mars.

Fatty acids and alkyl diols have comparatively longer records of preservation relative to ether lipids in the rock record on Earth, and they have been reported in sediments that are hundreds of millions to billions of years old (Han and Calvin, 1969; Van Hoeven et al., 1969). However, these studies were conducted before the widespread prevalence of contamination of ancient sediments from contemporary microbes was appreciated, and thus, further investigation into the longevity of these lipids is warranted. Nevertheless, these studies suggest that fatty acids, alkyl diols, and other bacterially derived lipids have the potential for long-term preservation on timescales consistent with the potential evolution of life on Mars.

Due to inorganic carbon limitation in serpentinizing systems (McCollom and Seewald, 2013; Schrenk et al., 2013) and the low concentrations of some lipids reported in this study (see Section 3), the successful identification of lipids in these habitats is likely reflective of lipid structural quality, rather than total lipid abundance. On Earth, early diagenetic processes can alter lipids, and they can form molecular fossils with notable patterns of degradation (Van Vleet and Quinn, 1979; Haddad et al., 1992; Reiche et al., 2018). For example, ether lipids are commonly preserved in the fossil record as biphytane hydrocarbons, which are the diagenetic products of GDGTs. The preferential degradation of unsaturated, methylated, and low-molecular-weight fatty acids relative to their higher molecular weight and saturated counterparts can also occur during early diagenesis, and later diagenetic effects can result in an alteration of fatty acid carbon chain length (Johnson and Calder, 1973; Matsuda and Koyama, 1977; Van Vleet and Quinn, 1979; Haddad et al., 1992). This suggests that the ability of lipids to persist through time as molecular fossils in the martian subsurface may be of paramount importance to their successful identification and recovery by future missions to Mars.

Here, we identify the solvent extractable organic compounds present in carbonate samples from the Samail Ophiolite. However, lipids can also be absorbed onto, or entrained within, minerals and/or preserved in recalcitrant macromolecular material (kerogen) during diagenesis due to the replacement of functional and/or other organic groups with cross-linked, insoluble components (Gobé et al., 2000; Pancost et al., 2008; Vandenbroucke and Largeau, 2007). Methods involving the chemical or thermal cleavage of organics from the macromolecular material, such as hydropyrolysis (Love et al., 1997; Maroto-Valer et al., 1997), have been utilized in the detection of kerogen-bound alkanes, steranes, hopanes (Murray et al., 1998), and archaeal lipids (Pancost et al., 2008) on Earth. These methods may be especially useful in extracting organic material from sediments that would otherwise generate low lipid yields. Thus, future investigations of macromolecular-bound products at the Samail Ophiolite and in other serpentinite-hosted environments on Earth will be critical to inform the planning for future rover missions to Mars with sample return.

A substantial challenge to the preservation of lipids on Mars is its inhospitable surface environment. Lipids may be altered or completely destroyed by chemical oxidation in high-energy environments, due to the prevalence of perchlorates in the martian regolith and exposure to ionizing radiation (Hays et al., 2017). Serpentinite-hosted environments would facilitate better preservation of lipids and other biosignatures than surface sediments because these are below the zone affected by solar and cosmic radiation. Moreover, 
these ecosystems efficiently buffer fluids to extremely lowoxygen fugacities, even within millimeters of Earth's oxidizing surface conditions. In addition to lipids, subsurface environments on Mars have the potential to preserve a suite of other biosignatures, including microbial structures and textures, isotopic signatures, and trace elements (Hays et al., 2017).

With the identification of alteration minerals throughout the martian southern highlands, it is likely that serpentinization was a common and widespread process on early Mars (Ehlmann et al., 2009, 2010; Amador et al., 2017, 2018). If, indeed, these regions are determined to have hosted ancient serpentinization processes, we suggest their potential as important locations for the long-term preservation of lipid biomarkers. Based on evidence from this study, we also highlight the diversity of lipids produced in serpentinitehosted environments.

\section{Conclusions}

Here, we present one of the first lipid biomarker records of a terrestrial serpentinite-hosted ecosystem, contributing to a growing understanding of the role of serpentinization processes in sustaining microbial life on Earth. The distributions of isoprenoidal and brGDGTs, MAGE, and fatty acids found at the Samail Ophiolite show strong similarities to those of biomarker assemblages identified at the submarine, serpentine-hosted $\mathrm{LCHF}$, providing evidence for a common core serpentinization lipidome that includes sulfate-reducing and ammonia-oxidizing bacteria, methanogens, and methanotrophs. Continuing investigations of the Samail Ophiolite and similar serpentinite-hosted ecosystems on Earth will help to build a robust molecular toolkit needed to identify and interpret putative biosignatures in serpentinizing systems on Mars and other terrestrial planets.

\section{Acknowledgments}

The authors acknowledge the members of the Summons laboratory (MIT), and they thank Evelyn Mervine (the De Beers Group of Companies) for her assistance in sample collection and Charles Settens (MIT CMSE) for his help with XRD analyses. S.A.N. thanks Andrew Whitehill (EPA), Bethany Elhmann, and James Dickson (Caltech) for helpful conversations. They also thank two anonymous reviewers and Astrobiology Editor In Chief, S.L. Cady for their helpful comments and suggestions.

\section{Author Disclosure Statement}

No competing financial interests exist.

\section{Funding Information}

Work by Kelemen, Mervine, and Shock was funded in part by NSF Research Grants EAR-1516300 and EAR-1049905, NASA grants 10-EXO10-0138 and 10-MFRP10-0098, and support from the International Continental Scientific Drilling Program and the Alfred P. Sloan Foundation. This work made use of the Shared Experimental Facilities supported in part by the MRSEC Program of the National Science Foundation under award number DMR - 1419807. S.O'R. acknowledges funding from Irish Research Council International Career Development Fellowships in Science, Engineering, and
Technology - Co-funded by the European Commission Marie Curie Actions Programme (Grant No. 291760). This work was also supported by awards from the NASA Astrobiology Institute (award NNA13AA90A) and the Simons Collaboration on the Origins of Life (award \#290361).

\section{Supplementary Material}

Supplementary Figure S1

Supplementary Figure S2

Supplementary Figure S3

Supplementary Table S1

Supplementary Table S2

Supplementary Table S3

Supplementary Table S4

\section{References}

Amador, E.S., Bandfield, J.L., Brazelton, W.J., and Kelley, D. (2017) The Lost City Hydrothermal Field: a spectroscopic and astrobiological analogue for Nili Fossae, Mars. Astrobiology 17:1138-1160.

Amador, E.S., Bandfield, J.L., and Thomas, N.H. (2018) A search for minerals associated with serpentinization across Mars using CRISM spectral data. Icarus 311:113-134.

Andrews-Hanna, J.C. and Lewis, K.W. (2011) Early Mars hydrology: 2. Hydrological evolution in the Noachian and Hesperian epochs. J Geophys Res 116:E02007.

Barnes, I., O'Neil, J.R., and Trescases, J.J. (1978) Present day serpentinization in New Caledonia, Oman and Yugoslavia. Geochim Cosmochim Acta 42:144-145.

Bath, A.H., Christofi, N., Neal, C., Philip, J.C., Cave, M.R., McKinley, I.G., and Berner, U. (1987) Trace element and microbiological studies of alkaline groundwaters in Oman, Arabian Gulf: a natural analogue for cement pore-waters. Rep. Fluid Processes Research Group, Brit Geol Surv FLPU: 87-92.

Becker, K.W., Lipp, J.S., Zhu, C., Liu, X.-L., and Hinrichs, K.-U. (2013) An improved method for the analysis of archaeal and bacterial ether core lipids. Org Geochem 61: 34-44.

Birgel, D., Himmler, T., Freiwald, A., and Peckmann, J. (2008) A new constraint on the antiquity of anaerobic oxidation of methane: late Pennsylvanian seep limestones from southern Namibia. Geology 36:543-546.

Blumenberg, M., Seifert, R., Reitner, J., Pape, T., and Michaelis, W. (2004) Membrane lipid patterns typify distinct anaerobic methanotrophic consortia. Proc Natl Acad Sci USA 101:11111-11116.

Boudier, F. and Coleman, R.G. (1981) Cross section through the peridotite in the Samail Ophiolite, southeastern Oman Mountains. J Geophys Res 86:2573-2592.

Boyd, E.S., Pearson, A., Pi, Y., Li, W.-J., Zhang, Y.G., He, L., Zhang, C.L., and Geesey, G.G. (2011) Temperature and pH controls on glycerol dibiphytanyl glycerol tetraether lipid composition in the hyperthermophilic crenarchaeon Acidilobus sulfurireducens. Extremophiles 15:59-65.

Bradley, A.S., Fredricks, H., Hinrichs, K.-U., and Summons, R.E. (2009a) Structural diversity of diether lipids in carbonate chimneys at the Lost City Hydrothermal Field. Org Geochem 40:1169-1178.

Bradley, A.S., Hayes, J.M., and Summons, R.E. (2009b) Extraordinary ${ }^{13} \mathrm{C}$ enrichment of diether lipids at the Lost City Hydrothermal Field indicates a carbon-limited ecosystem. Geochim Cosmochim Acta 73:102-118. 
Brazelton, W.J., Schrenk, M.O., Kelley, D.S., and Baross, J.A. (2006) Methane- and sulfur-metabolizing microbial communities dominate the Lost City Hydrothermal Field ecosystem. Appl Environ Microbiol 72:6257-6270.

Brazelton, W.J., Nelson, B., and Schrenk, M.O. (2012) Metagenomic evidence for $\mathrm{H}_{2}$ oxidation and $\mathrm{H}_{2}$ production by serpentinite-hosted subsurface microbial communities. Front Microbiol 2:268.

Brazelton, W.J., Thornton, C.N., Hyer, A., Twing, K.I., Longino, A.A., Lang, S.Q., Lilley, M.D., Früh-Green, G.L., and Schrenk, M.O. (2017) Metagenomic identification of active methanogens and methanotrophs in serpentinite springs of the Voltri Massif, Italy. Peer J 5:e2945.

Bruni, J., Canepa, M., Chiodini, G., Cioni, R., Cipolli, F., Longinelli, A., Marini, L., Ottonello, G., and Vetuschi Zuccolini, M. (2002) Irreversible water-rock mass transfer accompanying the generation of the neutral, $\mathrm{Mg}-\mathrm{HCO}_{3}$ and high-pH, Ca-OC spring waters of the Genova province, Italy. Appl Geochem 17:455-474.

Buschhaus, C., Peng, C., and Jetter, R. (2013) Very-long-chain 1,2- and 1,3-bifunctional compounds from the cuticular wax of Cosmos bipinnatus petals. Phytochemistry 91:249-256.

Cabrol, N.A. and Grin, E.A. (1999) Distribution, classification, and ages of Martian impact crater lakes. Icarus 142:160-172.

Canovas, P.A., III., Hoehler, T., and Shock, E.L. (2017) Geochemical bioenergetics during low-temperature serpentinization: an example from the Samail ophiolite, Sultanate of Oman. J Geophys Res 122:1821-1847.

Clark, I.D. and Fontes, J.-C. (1990) Paleoclimatic reconstruction in northern Oman based on carbonates from hyperalkaline groundwaters. Quat Res 33:320-336.

Coleman, R.G. (1981) Tectonic setting for ophiolite obduction in Oman. J Geophys Res 86:2497-2508.

Coleman, R.G. and Hopson, C.A. (1981) Oman Ophiolite Special Issue. J Geophys Res 86:2495-3132.

Daae, F.L., Økland, I., Dahle, H., Jørgensen, S.L., Thorseth, I.H., and Pedersen, R.B. (2013) Microbial life associated with low-temperature alteration of ultramafic rocks in the Leka ophiolite complex. Geobiology 11:318-339.

Ehlmann, B.L., Mustard, J.F., Swayze, G.A., Clark, R.N., Bishop, J.L., Poulet, F., Des Marais, D.J., Roach, L.H., Milliken, R.E., Wray, J.J., Barnouin-Jha, O., and Murchie, S.L. (2009) Identification of hydrated silicate minerals on Mars using MRO-CRISM: geologic context near Nili Fossae and implications for aqueous alteration. J Geophys Res 114:E00D08.

Ehlmann, B.L., Mustard, J.F., and Murchie, S.L. (2010) Geologic setting of serpentine deposits on Mars. Geophys Res Lett 37:L06201.

Ehlmann, B.L., Mustard, J.F., Murchie, S.L., Bibring, J.-P., Meunier, A., Fraeman, A.A., and Langevin, Y. (2011) Subsurface water and clay mineral formation during the early history of Mars. Nature 479:53-60.

Elling, F.J., Könneke, M., Nicol, G.W., Stieglmeier, M., Bayer, B., Spieck, E., de la Torre, J.R., Becker, K.W., Thomm, M., Prosser, J.I., Herndl, G.J., Schleper, C., and Hinrichs, K.-U. (2017) Chemotaxonomic characterisation of the thaumarchaeal lipidome. Environ Microbiol 19:2681-2700.

Eslami, A., Tutolo, B.M., Evans, K.A. Kahl, W.-A., Godard, M., Kelemen, P.B., Michibayashi, K., Takazawa, E., Teagle, D.A.H., and the Oman Drilling Project Phase 2 Science Party (2018) A reconnaissance petrographic study of opaque mineral assemblages in peridotites and mafic dykes from the Oman Drilling Project holes BA1B, BA3A and BA4A. AGU Fall Meeting Abstracts V13E-0137.
Etiope, G. (2017) Reply to "Methane origin in the Samail ophiolite: comment on 'Modern water/rock reactions in Oman hyperalkaline peridotite aquifers and implications for microbial habitability.' " [Geochim Cosmochim Acta 179 (2016) 217-241]. Geochim Cosmochim Acta 197:467-470.

Etiope, G. and Sherwood Lollar, B. (2013) Abiotic methane on Earth. Rev Geophys 51:276-299.

Fassett, C.I. and Head, J.W., III. (2008) Valley network-fed, open-basin lakes on Mars: distribution and implications for Noachian surface and subsurface hydrology. Icarus 198: 37-56.

Fones, E.M., Colman, D.R., Kraus, E.A., Nothaft, D.B., Rempfert, K.R., Spear, J.R., Templeton, A.S., Boyd, E.S., and Boyd, E.S. (2019) Physiological adaptations to serpentinization in the Samail Ophiolite, Oman. ISME J 13:1750-1762.

Frost, B.R. (1985) On the stability of sulfides, oxides, and native metals in serpentinite. J Petrol 26:31-63.

Glennie, K.W., Boeuf, M.G.A., Hughes-Clarke, M.W., MoodyStuart, M., Pilaar, W.F.H., and Reinhardt, B.M. (1974) Geology of the Oman Mountains. Part One, Part Two (tables and illustrations), Part Three (enclosures). Kon Ned Geol Miinhoukundia Genoot Ver 31:423.

Gobé, V., Lemée, L., and Amblès, A. (2000) Structure elucidation of soil macromolecular lipids by preparative pyrolysis and thermochemolysis. Org Geochem 31:409-419.

Godard, M., Jousselin, D., Bodinier, J.-L. (2000) Relationships between geochemistry and structure beneath a palaeospreading centre: a study of the mantle section in the Oman ophiolite. Earth Planet Sci Lett 180:133-148.

Godard, M., Dautria, J.-M., Perrin, M. (2003) Geochemical variability of the Oman ophiolite lavas: relationship with spatial distribution and paleomagnetic directions. Geochem Geophys Geosyst 4:8609.

Goudge, T.A., Fassett, C.I., Head, J.W., Mustard, J.F., and Aureli, K.L. (2016) Insights into surface runoff on early Mars from paleolake basin morphology and stratigraphy. Geology 44:419-422.

Greenberger, R.N., Mustard, J.F., Cloutis, E.A., Pratt, L.M., Sauer, P.E., Mann, P., Turner, K., Dyar, M.D., and Bish, D.L. (2015) Serpentinization, iron oxidation, and aqueous conditions in an ophiolite: implications for hydrogen production and habitability on Mars. Earth Planet Sci Lett 416:21-34.

Grossi, V., Mollex, D., Vinçon-Laugier, A., Hakil, F., Pacton, M., and Cravo-Laureau, C. (2015) Mono- and dialkyl glycerol ether lipids in anaerobic bacteria: biosynthetic insights from the mesophilic sulfate reducer Desulfatibacillum alkenivorans PF2803 ${ }^{\mathrm{T}}$. Appl Environ Microbiol 81:3157-3168.

Hacker, B.R. (1994) Rapid emplacement of young oceanic lithosphere: argon geochronology of the Oman ophiolite. Science 265:1563-1565.

Haddad, R.I., Martens, C.S., and Farrington, J.W. (1992) Quantifying early diagenesis of fatty acids in a rapidly accumulating coastal marine sediment. Org Geochem 19:205216.

Halevy, I. and Head, J.W., III. (2014) Episodic warming of early Mars by punctuated volcanism. Nat Geosci 7:865-868.

Han, J. and Calvin, M. (1969) Occurrence of fatty acids and aliphatic hydrocarbons in a 3.4 billion-year-old sediment. Nature 224:576-577.

Hanghøj, K., Kelemen, P.B., Hassler, D., and Godard, M. (2010) Composition and genesis of depleted mantle peridotites from the Wadi Tayin massif, Oman ophiolite; major and trace element geochemistry, and Os isotope and PGE systematics. J Petrol 51:201-227. 
Hays, L.E., Graham, H.V., Des Marais, D.J., Hausrath, E.M., Horgan, B., McCollom, T.M., Parenteau, M.N., PotterMcIntyre, S.L., Williams, A.J., and Lynch, K.L. (2017) Biosignature preservation and detection in Mars analog environments. Astrobiology 17:363-400.

Hernandez-Sanchez, M.T., Homoky, W.B., and Pancost, R.D. (2014) Occurrence of 1-O-monoalkyl glycerol ether lipids in ocean waters and sediments. Org Geochem 66:1-13.

Holm, N.G., Oze, C., Mousis, O., Waite, J.H., and GuilbertLepoutre, A. (2015) Serpentinization and the formation of $\mathrm{H}_{2}$ and $\mathrm{CH}_{4}$ on celestial bodies (planets, moons, comets). Astrobiology 15:587-600.

Huguet, C., Hopmans, E.C., Febo-Ayala, W., Thompson, D.H., Sinninghe Damsté, J.S., Schouten, S. (2006) An improved method to determine the absolute abundance of glycerol dibiphytanyl glycerol tetraether lipids. Org Geochem 37:10361041.

Johnson, R.W. and Calder, J.A. (1973) Early diagenesis of fatty acids and hydrocarbons in a salt marsh environment. Geochim Cosmochim Acta 37:1943-1955.

Kelemen, P.B. and Matter, J. (2008) In situ carbonation of peridotite for $\mathrm{CO}_{2}$ storage. Proc Natl Acad Sci 105:1729517300.

Kelemen, P.B., Matter, J., Streit, E.E., Rudge, J.F., Curry, W.B., and Blusztajn, J. (2011) Rates and mechanisms of mineral carbonation in peridotite: natural processes and recipes for enhanced, in situ $\mathrm{CO}_{2}$ capture and storage. Annu Rev Earth Planet Sci 39:545-576.

Kelemen, P.B., Bach, W., Evans, K.A., Eslami, A., Farough, A., Hamada, M., Ichiyama, Y., Kahl, W.-A., Matter, J.M., Pezard, P.A., Paukert Vankeuren, A.N., Godard, M., Michibayashi, K., Choe, S., Coggon, J.A., and the Oman Drilling Project Scientific Party (2018) Correlated variation in vein type, vein frequency, $\mathrm{pH}$, oxygen fugacity and depth in Oman Drilling Project Holes BA1B, BA3A and BA4A. AGU Fall Meeting Abstracts V12B-03.

Kelley, D.S., Karson, J.A., Früh-Green, G.L., Yoerger, D.R., Shank, T.M., Butterfield, D.A., Hayes, J.M., Schrenk, M.O., Olson, E.J., Proskurowski, G., Jakuba, M., Bradley, A., Larson, B., Ludwig, K., Glickson, D., Buckman, K., Bradley, A.S., Brazelton, W.J., Roe, K., Elend, M.J., Delacour, A., Bernasconi, S.M., Lilley, M.D., Baross, J.A., Summons, R.E., and Sylva, S.P. (2005) A serpentinite-hosted ecosystem: the Lost City Hydrothermal Field. Science 307:14281434.

Klein, F. and Bach, W. (2009) Fe-Ni-Co-O-S phase relations in peridotite-seawater interactions. J Petrol 50:37-59.

Klein, F., Bach, W., Jöns, N., McCollom, T., Moskowitz, B., and Berquó, T. (2009) Iron partitioning and hydrogen generation during serpentinization of abyssal peridotites from $15^{\circ} \mathrm{N}$ on the Mid-Atlantic Ridge. Geochim Cosmochim Acta 73:6868-6893.

Klein, F., Humphris, S.E., Guo, W., Schubotz, F., Schwarzenbach, E.M., and Orsi, W.D. (2015) Fluid mixing and the deep biosphere of a fossil Lost City-type hydrothermal system at the Iberia Margin. Proc Natl Acad Sci 112:12036-12041.

Koga, Y. and Morii, H. (2005) Recent advances in structural research on ether lipids from archaea including comparative and physiological aspects. Biosci Biotechnol Biochem 69: 2019-2034.

Koga, Y., Nishihara, M., Morii, H., and Akagawa-Matsushita, M. (1993) Ether polar lipids of methanogenic bacteria: structures, comparative aspects and biosyntheses. Microbiol Rev 57:164-182.
Könneke, M., Bernhard, A.E., de la Torre, J.R., Walker, C.B., Waterbury, J.B., and Stahl, D.A. (2005) Isolation of an autotrophic ammonia-oxidizing marine archaeon. Nature 437: 543-546.

Koopmans, M.P., Sinninghe Damsté, J.S., Lewan, M.D., and de Leeuw, J.W. (1995) Thermal stability of thiophene biomarkers as studied by hydrous pyrolysis. Org Geochem 23: 583-596.

Koopmans, M.P., de Leeuw, J.W., Lewan, M.D., and Sinninghe Damsté, J.S. (1996) Impact of dia- and catagenesis on sulphur and oxygen sequestration of biomarkers as revealed by artificial maturation of an immature sedimentary rock. Org Geochem 25:391-426.

Lang, S.Q., Früh-Green, G.L., Bernasconi, S.M., and Butterfield, D.A. (2013) Sources of organic nitrogen at the serpentinite-hosted Lost City Hydrothermal Field. Geobiology 11:154-169.

Langworthy, T.A., Holzer, G., Zeikus, J.G., and Tornabene, T.G. (1983) Iso- and anteiso-branched glycerol diethers of the thermophilic anaerobe Thermodesulfotobacterium commune. Syst Appl Microbiol 4:1-17.

Leininger, S., Urich, T., Schloter, M., Schwark, L., Qi, J., Nicol, G.W., Prosser, J.I., Schuster, S.C., and Schleper, C. (2006) Archaea predominate among ammonia-oxidizing prokaryotes in soils. Nature 442:806-809.

Li, H., Lü, X., Tao, C., Han, T., Hu, P., Zhang, G., Yu, Z., Dong, C., and Shao, Z. (2018) Distribution of tetraether lipids in sulfide chimneys at the Deyin hydrothermal field, southern Mid-Atlantic Ridge: implication to chimney growing stage. Sci Rep 8:8060.

Lincoln, S.A., Bradley, A.S., Newman, S.A., and Summons, R.E. (2013) Archaeal and bacterial glycerol dialkyl glycerol tetraether lipids in chimneys of the Lost City Hydrothermal Field. Org Geochem 60:45-53.

Lincoln, S.A., Wai, B., Eppley, J.M., Church, M.J., Summons, R.E., and DeLong, E.F. (2014) Planktonic Euryarchaeota are a significant source of archaeal tetraether lipids in the ocean. Proc Natl Acad Sci 111:9858-9863.

Lipp, J.S. and Hinrichs, K.-U. (2009) Structural diversity and fate of intact polar lipids in marine sediments. Geochim Cosmochim Acta 73:6816-6833.

Logemann, J., Graue, J., Köster, J., Engelen, B., Rullkötter, J., and Cypionka, H. (2011) A laboratory experiment of intact polar lipid degradation in sandy sediments. Biogeosciences 8: 2547-2560.

Lorand, J.P. (1988) Fe-Ni-Cu sulfides in tectonite peridotites from the Maqsad district, Sumail ophiolite, southern Oman: implications for the origin of the sulfide component in the oceanic upper mantle. Tectonophysics 151:57-73.

Love, G.D., McAulay, A., Snape, C.E., and Bishop, A.N. (1997) Effect of process variables in catalytic hydropyrolysis on the release of covalently bound aliphatic hydrocarbons from sedimentary organic matter. Energy Fuels 11:522-531.

Love, G.D., Grosjean, E., Stalvies, C., Fike, D.A., Grotzinger, J.P., Bradley, A.S., Kelly, A.E., Bhatia, M., Meredith, W., Snape, C.E., Bowring, S.A., Condon, D.J., and Summons, R.E. (2009) Fossil steroids record the appearance of Demospongiae during the Cryogenian period. Nature 457:718721.

Maroto-Valer, M.M., Love, G.D., and Snape, C.E. (1997) Close correspondence between carbon skeletal parameters of kerogens and their hydropyrolysis oils. Energy Fuels 11:539-545. Martens-Habbena, W., Berube, P.M., Urakawa, H., de la Torre, J.R., and Stahl, D.A. (2009) Ammonia oxidation kinetics 
determine niche separation of nitrifying Archaea and Bacteria. Nature 461:976-979.

Martin, W., Baross, J., Kelley, D., and Russell, M.J. (2008) Hydrothermal vents and the origin of life. Nat Rev Microbiol 6:805-814.

Matsuda, H. and Koyama, T. (1977) Early diagenesis of fatty acids in lacustrine sediments-I. Identification and distribution of fatty acids in recent sediment from a freshwater lake. Geochim Cosmochim Acta 41:777-783.

Mayhew, L.E., Ellison, E.T., Miller, H.M., Kelemen, P.B., and Templeton, A.S. (2018) Iron transformations during low temperature alteration of variably serpentinized rocks from the Samail ophiolite, Oman. Geochim Cosmochim Acta 222: 704-728.

McCollom, T.M. and Bach, W. (2009) Thermodynamic constraints on hydrogen generation during serpentinization of ultramafic rocks. Geochim Cosmochim Acta 73:856-875.

McCollom, T.M. and Seewald, J.S. (2013) Serpentinites, hydrogen, and life. Elements 9:129-134.

Méhay, S., Früh-Green, G.L., Lang, S.Q., Bernasconi, S.M., Brazelton, W.J., Schrenk, M.O., Schaeffer, P., and Adam, P. (2013) Record of archaeal activity at the serpentinitehosted Lost City Hydrothermal Field. Geobiology 11:570592.

Mervine, E.M., Humphris, S.E., Sims, K.W.W., Kelemen, P.B., and Jenkins, W.J. (2014) Carbonation rates of peridotite in the Samail Ophiolite, Sultanate of Oman, constrained through ${ }^{14} \mathrm{C}$ dating and stable isotopes. Geochim Cosmochim Acta 126:371-397.

Miller, H.M., Matter, J.M., Kelemen, P., Ellison, E.T., Conrad, M.E., Fierer, N., Ruchala, T., Tominaga, M., and Templeton, A.S. (2016) Modern water/rock reactions in Oman hyperalkaline peridotite aquifers and implications for microbial habitability. Geochim Cosmochim Acta 179:217-241.

Miller, H.M., Mayhew, L.E., Ellison, E.T., Kelemen, P., Kubo, M., Templeton, A.S. (2017) Low temperature hydrogen production during experimental hydration of partiallyserpentinized dunite. Geochim Cosmochim Acta 209:161183.

Monnier, C., Girardeau, J., Le Mée, L., and Polvé, M. (2006) Along-ridge petrological segmentation of the mantle in the Oman ophiolite. Geochem Geophys Geosyst 7:Q11008.

Moore, J.M. and Howard, A.D. (2005) Large alluvial fans on Mars. J Geophys Res 110:E04005.

Murray, I.P., Love, G.D., Snape, C.E., and Bailey, N.J.L. (1998) Comparison of covalently-bound aliphatic biomarkers released via hydropyrolysis with their solvent-extractable counterparts for a suite of Kimmeridge clays. Org Geochem 29:1487-1505.

Neal, C. and Stanger, G. (1983) Hydrogen generation from mantle source rocks in Oman. Earth Planet Sci Lett 66:315320.

Neal, C., and Stanger, G. (1985) Past and present serpentinisation of ultramafic rocks; an example from the Semail Ophiolite Nappe of Northern Oman. In The Chemistry of Weathering, edited by J.I. Drever, Springer, Dordrecht, Netherlands, pp 249-276.

Nichols, P.D., Guckert, J.B., and White, D.C. (1986) Determination of monounsaturated fatty acid double-bond position and geometry for microbial monocultures and complex consortia by capillary GC-MS of their dimethyl disulphide adducts. J Microbiol Methods 5:49-55.

Nicolas, A., Boudier, F., Ildefonse, B., and Ball, E. (2000) Accretion of Oman and United Arab Emirates ophiolite- discussion of a new structural map. Mar Geophys Res 21: 147-180.

O'Reilly, S.S., Mariotti, G., Winter, A.R., Newman, S.A., Matys, E.D., McDermott, F., Pruss, S.B., Bosak, T., Summons, R.E., and Klepac-Ceraj, V. (2017) Molecular biosignatures reveal common benthic microbial sources of organic matter in ooids and grapestones from Pigeon Cay, The Bahamas. Geobiology 15:112-130.

Oren, A. (2014) Halophilic archaea on Earth and in space: growth and survival under extreme conditions. Philos Trans $R$ Soc A 372:20140194.

Pan, A., Yang, Q., Zhou, H., Ji, F., Wang, H., and Pancost, R.D. (2016) A diagnostic GDGT signature for the impact of hydrothermal activity on surface deposits at the Southwest Indian Ridge. Org Geochem 99:90-101.

Pancost, R.D., Coleman, J.M., Love, G.D., Chatzi, A., Bouloubassi, I., and Snape, C.E. (2008) Kerogen-bound glycerol dialkyl tetraether lipids released by hydropyrolysis of marine sediments: a bias against incorporation of sedimentary organisms? Org Geochem 39:1359-1371.

Pancost, R.D., Hopmans, E.C., Sinninghe Damsté, J.S., and The MEDINAUT Shipboard Scientific Party (2001) Archaeal lipids in Mediterranean Cold Seeps: molecular proxies for anaerobic methane oxidation. Geochim Cosmochim Acta 65: 1611-1627.

Pancost, R.D., Pressley, S., Coleman, J.M., Benning, L.G., and Mountain, B.W. (2005) Lipid biomolecules in silica sinters: indicators of microbial biodiversity. Environ Microbiol 7:6677.

Paukert, A.N., Matter, J.M., Kelemen, P.B., Shock, E.L., and Havig, J.R. (2012) Reaction path modeling of enhanced in situ $\mathrm{CO}_{2}$ mineralization for carbon sequestration in the peridotite of the Samail Ophiolite, Sultanate of Oman. Chem Geol 330-331:86-100.

Paukert Vankeuren, A.N., Matter, J.M., Stute, M., and Kelemen, P.B. (2019) Multitracer determination of apparent groundwater ages in peridotite aquifers within the Samail Ophiolite, Sultanate of Oman. Earth Planet Sci Lett 516:37-48.

Pease, T.K., Van Vleet, E.S., Barre, J.S., and Dickins, H.D. (1998) Simulated degradation of glyceryl ethers by hydrous and flash pyrolysis. Org Geochem 29:979-988.

Peterse, F., Kim, J.-H., Schouten, S., Kitgaard Kristensen, D., Koç, N., and Sinninghe Damsté, J.S. (2009) Constraints on the application of the MBT/CBT palaeothermometer at high latitude environments (Svalbard, Norway). Org Geochem 40: 692-699.

Pond, J.L., Langworthy, T.A., and Holzer, G. (1986) Longchain diols: a new class of membrane lipids from a thermophilic bacterium. Science 231:1134-1136.

Quéméneur, M., Palvadeau, A., Postec, A., Monnin, C., Chavagnac, V., Ollivier, B., and Erauso, G. (2015) Endolithic microbial communities in carbonate precipitates from serpentinite-hosted hyperalkaline springs of the Voltri Massif (Ligurian Alps, Northern Italy). Environ Sci Pollut Res 22: 13613-13624.

Reiche, S., Rampen, S.W., Dorhout, D.J.C., Sinninghe Damsté, J.S., and Schouten, S. (2018) The impact of oxygen exposure on long-chain alkyl diols and the long chain diol index (LDI) - a long-term incubation study. Org Geochem 124: 238-246.

Rempfert, K.R., Miller, H.M., Bompard, N., Nothaft, D., Matter, J.M., Kelemen, P., Fierer, N., and Templeton, A.S. (2017) Geological and geochemical controls on subsurface microbial life in the Samail ophiolite, Oman. Front Microbiol 8:56. 
Rioux, M., Bowring, S., Kelemen, P., Gordon, S., Dudás, F., and Miller, R. (2012) Rapid crustal accretion and magma assimilation in the Oman-U.A.E. ophiolite: high precision $\mathrm{U}-\mathrm{Pb}$ zircon geochronology of the gabbroic crust. $J$ Geophys Res 117:B07201.

Rioux, M., Bowring, S., Kelemen, P., Gordon, S., Miller, R., and Dudás, F. (2013) Tectonic development of the Samail ophiolite: high-precision U-Pb zircon geochronology and SmNd isotopic constraints on crustal growth and emplacement. $J$ Geophys Res 118:2085-2101.

Rioux, M., Garber, J., Bauer, A., Bowring, S., Searle, M., Kelemen, P., and Hacker, B. (2016) Synchronous formation of the metamorphic sole and igneous crust of the Semail ophiolite: new constraints on the tectonic evolution during ophiolite formation from high-precision $\mathrm{U}-\mathrm{Pb}$ zircon geochronology. Earth Planet Sci Lett 451:185-195.

Russell, M.J., Hall, A.J., and Martin, W. (2010) Serpentinization as a source of energy at the origin of life. Geobiology 8: 355-371.

Rütters, H., Sass, H., Cypionka, H., and Rullkötter, J. (2001) Monoalkylether phospholipids in the sulfate-reducing bacteria Desulfosarcina variabilis and Desulforhabdus amnigenus. Arch Microbiol 176:435-442.

Saito, R., Kaiho, K., Oba, M., Fujibayashi, M., Tong, J., and Tian, L. (2015) Predominance of archaea-derived hydrocarbons in an Early Triassic microbialite. Org Geochem 85:66-75.

Saito, R., Kaiho, K., Oba, M., Tong, J., Chen, Z.-Q., Tian, L., Takahashi, S., and Fujibayashi, M. (2017) Tentative identification of diagenetic products of cyclic biphytanes in sedimentary rocks from the uppermost Permian and Lower Triassic. Org Geochem 111:144-153.

Schouten, S., Hopmans, E.C., Schefuß, E., and Sinninghe Damsté, J.S. (2002) Distributional variations in marine crenarchaeol membrane lipids: a new tool for reconstructing ancient sea water temperatures? Earth Planet Sci Lett 204: 265-274.

Schrenk, M.O., Brazelton, W.J., and Lang, S.Q. (2013) Serpentinization, carbon, and deep life. Rev Miner Geochem 75: 575-606.

Schulte, M., Blake, D., Hoehler, T., and McCollom, T. (2006) Serpentinization and its implications for life on the early Earth and Mars. Astrobiology 6:364-376.

Simoneit, B.R.T., Summons, R.E., and Jahnke, L.L. (1998) Biomarkers as tracers for life on early Earth and Mars. Orig Life Evol Biosph 28:475-483.

Simoneit, B.R.T., Lein, A.Y., Peresypkin, V.I., and Osipov, G.A. (2004) Composition and origin of hydrothermal petroleum and associated lipids in the sulfide deposits of the Rainbow Field (Mid-Atlantic Ridge at $36^{\circ} \mathrm{N}$ ). Geochim Cosmochim Acta 68:2275-2294.

Sinninghe Damsté, J.S., Ossebaar, J., Abbas, B., Schouten, S., and Verschuren, D. (2009) Fluxes and distribution of tetraether lipids in an equatorial African lake: constraints on the application of the TEX $_{86}$ palaeothermometer and BIT index in lacustrine settings. Geochim Cosmochim Acta 73:4232-4249.

Sleep, N.H., Meibom, A., Fridriksson, Th., Coleman, R.G., and Bird, D.K. (2004) $\mathrm{H}_{2}$-rich fluids from serpentinization: geochemical and biotic implications. Proc Natl Acad Sci 101: 12818-12823.

Suzuki, S., Ishii, S., Wu, A., Cheung, A., Tenney, A., Wanger, G., Kuenen, J.G., and Nealson, K.H. (2013) Microbial diversity in The Cedars, an ultrabasic, ultrareducing, and low salinity serpentinizing ecosystem. Proc Natl Acad Sci 110: 15336-15341.
Talbot, H.M., Watson, D.F., Murrell, J.C., Carter, J.F., and Farrimond, P. (2001) Analysis of intact bacteriohopanepolyols from methanotrophic bacteria by reversedphase high-performance liquid chromatography-atmospheric pressure chemical ionisation mass spectrometry. J Chromatogr A 921:175-185.

Tamura, A. and Arai, S. (2006) Harzburgite-duniteorthopyroxenite suite as a record of supra-subduction zone setting for the Oman ophiolite mantle. Lithos 90:43-56.

Thurl, S. and Schäfer, W. (1988) Lipids from the sulphurdependent archaebacterium Thermoproteus tenax. Biochim Biophys Acta 961:253-261.

Tiago, I. and Veríssimo, A. (2013) Microbial and functional diversity of a subterrestrial high $\mathrm{pH}$ groundwater associated to serpentinization. Environ Microbiol 15:1687-1706.

Tierney, J.E. and Russell, J.M. (2009) Distributions of branched GDGTs in a tropical lake system: implications for lacustrine application of the MBT/CBT paleoproxy. Org Geochem 40: 1032-1036.

Tierney, J.E., Russell, J.M., Eggermont, H., Hopmans, E.C., Verschuren, D., and Sinninghe Damsté, J.S. (2010) Environmental controls on branched tetraether lipid distributions in tropical East African lake sediments. Geochim Cosmochim Acta 74:4902-4918.

Tilton, G.R., Hopson, C.A., and Wright, J.E. (1981) Uraniumlead isotopic ages of the Samail Ophiolite, Oman, with applications to Tethyan ocean ridge tectonics. J Geophys Res 86:2763-2775.

Trincone, A., Nicolaus, B., Palmieri, G., De Rosa, M., Huber, R., Huber, G., Stetter, K.O., and Gambacorta, A. (1992) Distribution of complex and core lipids within new hyperthermophilic members of the archaea domain. Syst Appl Microbiol 15:11-17.

Vandenbroucke, M. and Largeau, C. (2007) Kerogen origin, evolution and structure. Org Geochem 38:719-833.

van der Meer, M.T.J., Schouten, S., Hanada, S., Hopmans, E.C., Sinninghe Damsté, J.S., and Ward, D.M. (2002) Alkane-1,2diol-based glycosides and fatty glycosides and wax esters in Roseiflexus castenholzii and hot spring microbial mats. Arch Microbiol 178:229-237.

Van Hoeven, W., Maxwell, J.R., and Calvin, M. (1969) Fatty acids and hydrocarbons as evidence of life processes in ancient sediments and crude oils. Geochim Cosmochim Acta 33: 877-881.

Van Vleet, E.S. and Quinn, J.G. (1979) Early diagenesis of fatty acids and isoprenoid alcohols in estuarine and coastal sediments. Geochim Cosmochim Acta 43:289-303.

van Winden, J.F., Talbot, H.M., Kip, N., Reichart, G.-J., Pol, A., McNamara, N.P., Jetten, M.S.M., Op den Camp, H.J.M., and Sinninghe Damsté, J.S. (2012) Bacteriohopanepolyol signatures as markers for methanotrophic bacteria in peat moss. Geochim Cosmochim Acta 77:52-61.

Vinçon-Laugier, A., Grossi, V., Pacton, M., Escarguel, G., and Cravo-Laureau, C. (2016) The alkyl glycerol ether lipid composition of heterotrophic sulfate reducing bacteria strongly depends on growth substrate. Org Geochem 98:141-154.

Vinçon-Laugier, A., Cravo-Laureau, C., Mitteau, I., and Grossi, V. (2017) Temperature-dependent alkyl glycerol ether lipid composition of mesophilic and thermophilic sulfate-reducing bacteria. Front Microbiol 8:1532.

Völkl, P., Huber, R., Drobner, E., Rachel, R., Burggraf, S., Trincone, A., and Stetter, K.O. (1993) Pyrobaculum aerophilum sp. nov., a novel nitrate-reducing hyperthermophilic archaeum. Appl Environ Microbiol 59:2918-2926. 
Wait, R., Carreto, L., Nobre, M.F., Ferreira, A.M., and da Costa, M.S. (1997) Characterization of novel long-chain 1,2diols in Thermus species and demonstration that Thermus strains contain both glycerol-linked and diol-linked glycolipids. J Bacteriol 179:6154-6162.

Wang, Y. and $\mathrm{Xu}, \mathrm{Y}$. (2016) Distribution and source of 1-Omonoalkyl glycerol ethers in the Yellow River and Bohai Sea. Org Geochem 91:81-88.

Warner, N., Gupta, S., Lin, S.-Y., Kim, J.-R., Muller, J.-P., and Morley, J. (2010) Late Noachian to Hesperian climate change on Mars: evidence of episodic warming from transient crater lakes near Ares Vallis. J Geophys Res 115:E06013.

Weijers, J.W.H., Schouten, S., Spaargaren, O.C., and Sinninghe Damsté, J.S. (2006) Occurrence and distribution of tetraether membrane lipids in soils: implications for the use of the TEX 86 proxy and the BIT index. Org Geochem 37:1680-1693.

Weijers, J.W.H., Panoto, E., van Bleijswijk, J. Schouten, S., Rijpstra, W.I.C., Balk, M., Stams, A.J.M., and Sinninghe Damsté, J.S. (2009) Constraints on the biological source(s) of the orphan branched tetraether membrane lipids. Geomicrobiol $J$ 26:402-414.

Willerslev, E., Hansen, A.J., Rønn, R., Brand, T.B., Barnes, I., Wiuf, C., Gilichinsky, D., Mitchell, D., and Cooper, A. (2004) Long-term persistence of bacterial DNA. Curr Biol 14:R9-R10.

Woycheese, K.M., Meyer-Dombard, D.R., Cardace, D., Argayosa, A.M., and Arcilla, C.A. (2015) Out of the dark: transitional subsurface-to-surface microbial diversity in a terrestrial serpentinizing seep (Manleluag, Pangasinan, the Philippines). Front Microbiol 6:44.

Yang, H., Zheng, F., Xiao, W., and Xie, S. (2015) Distinct distribution revealing multiple bacterial sources for $1-O$ monoalkyl glycerol ethers in terrestrial and lake environments. Sci China Earth Sci 58:1005-1017.

Zeng, Y.B., Ward, D.M., Brassell, S.C., and Eglinton, G. (1992) Biogeochemistry of hot spring environments: 2. Lipid compositions of Yellowstone (Wyoming, U.S.A.) cyanobacterial and Chloroflexus mats. Chem Geol 95:327-345.

Zhang, C.L., Pancost, R.D., Sassen, R., Qian, Y., and Macko, S.A. (2003) Archaeal lipid biomarkers and isotopic evidence of anaerobic methane oxidation associated with gas hydrates in the Gulf of Mexico. Org Geochem 34:827-836.

Zwicker, J., Birgel, D., Bach, W., Richoz, S., Smrzka, D., Grasemann, B., Gier, S., Schleper, C., Rittmann, S.K.-M.R., Koşun, E., and Peckmann, J. (2018) Evidence for archaeal methanogenesis within veins at the onshore serpentinitehosted Chimaera seeps, Turkey. Chem Geol 483:567-580.

Address correspondence to: Sharon A. Newman Division of Geological and Planetary Sciences California Institute of Technology 1200 E. California Boulevard Mail Code: 170-25 Pasadena, CA 91125

E-mail: snewman@caltech.edu

Submitted 12 March 2019 Accepted 4 February 2020

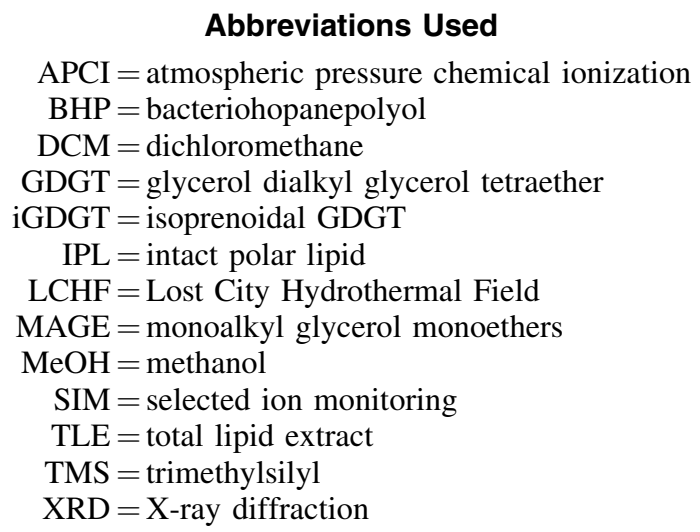

